\title{
Laser Ablation-Inductively Coupled Plasma- Atomic Emission Spectroscopy Study at the 222-S Laboratory Using Hot-Cell Glove Box Prototype System
}

\author{
C. M. Seidel, J. Jain, and J. W. Owens \\ Washington River Protection Solutions LLCC \\ Richland, WA 99352 \\ U.S. Department of Energy Contract DE-AC27-08RV14800
EDT/ECN: DRF UC:
Cost Center: $\quad$ Charge Code: 2EK00
B\&R Code:
Total Pages:
644 including DRF and this page
$34 \quad 28 B 2 \cdot 23.09$

Key Words: Laser Ablation, Task Order 2005-003, LA-ICP-AES, Waste Treatment and Immobilization Plant;

Abstract: This report describes the installation, testing, and acceptance of the Waste Treatment and Immobilization Plant (WTP) procured laser ablation-inductively coupled plasma-atomic emission spectroscopy (LA-ICP-AES) system for remotely analyzing high-level waste (HLW) samples in a hot cell environment. The work was completed by the Analytical Process Development (APD) group in accordance with Task Order 2005-003; ATS MP 1027, Management Plan for Waste Treatment Plant Project Work Performed by Analytical Technical Services. The APD group at the 222-S Laboratory demonstrated acceptable turnaround time (TAT) and provide sufficient data to assess sensitivity, accuracy, and precision of the LA-ICP-AES method.

TRADEMARK DISCLAIMER. Reference herein to any specific commercial product, process, or service by trade name, trademark, manufacturer, or otherwise, does not necessarily constitute or imply its endorsement, recommendation, or favoring by the United States Government or any agency thereof or its contractors or subcontractors.

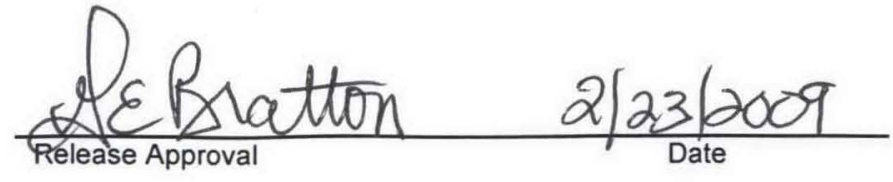

Approved For Public Release

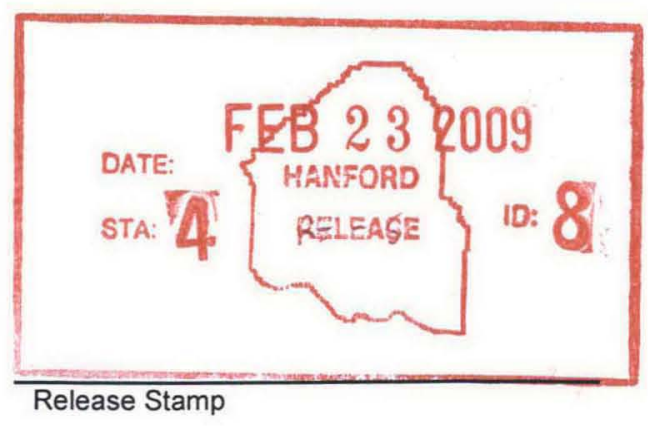




\section{Laser Ablation-Inductively Coupled Plasma-Atomic Emission Spectroscopy Study at the 222-S Laboratory Using Hot-Cell Glove Box Prototype System}

Washington River Protection Solutions LLC

Date Published

February 2009

washington river
protection solutions

Prepared for the U.S. Department of Energy

Office of River Protection

Contract No. DE-AC27-08RV14800 
RPP-RPT-39823, Rev. 0

\section{EXECUTIVE SUMMARY}

This report describes the installation, testing, and acceptance of the Waste Treatment and Immobilization Plant (WTP) procured laser ablation-inductively coupled plasma-atomic emission spectroscopy (LA-ICP-AES) system for remotely analyzing high-level waste (HLW) samples in a hot cell environment. The method tested in this study was developed through a team effort at Savannah River National laboratory (SRNL) (WSRC-TR-2005-00260, The Development of Laser Ablation-Inductively Coupled Plasma-Atomic Emission Spectroscopy for the Analysis of Hanford High Level Waste), and Pacific Northwest National laboratory (WTP-RPT-140, Laser Ablation/ICP-AES Time Study). The work was completed by the Analytical Process Development (APD) group in accordance with the task plan (Appendix A) that addresses the scope defined by Memorandum of Agreement CHG-BNI-2001; Task Order 2005-003; ATS-MP-1027, Management Plan for Waste Treatment Plant Project Work Performed by Analytical Technical Services, as directed by statement of work authorized by Bechtel National, Inc. The APD group at the 222-S Laboratory was requested to demonstrate acceptable turnaround time (TAT) and provide sufficient data to assess sensitivity, accuracy, and precision of the LA-ICP-AES method.

This work began with the APD assisting WTP in the procurement of the prototype LA-ICP-AES glove box system and subsequent installation in the hot cell facility of the 222-S Laboratory. The system was tested for operability prior to initiating the analytical work specified in the task plan (Appendix A). The LA-ICP-AES was calibrated using the known glass coupons that were prepared and characterized at SRNL.

Scoping tests were performed on a radioactive AY-102 sample that was prepared at SRNL by vitrifying the HLW slurry into a glass coupon. The sample was analyzed for 23 elements (Al, B, $\mathrm{Ca}, \mathrm{Cd}, \mathrm{Cr}, \mathrm{Fe}, \mathrm{K}, \mathrm{Li}, \mathrm{Mg}, \mathrm{Mn}, \mathrm{Na}, \mathrm{Ni}, \mathrm{P}, \mathrm{S}, \mathrm{Sb}, \mathrm{Si}, \mathrm{Sr}$, Th, Ti, Tl, U, Zn, and Zr). Lithium borate glass was included as a blank and an analytical reference glass (ARG-1) was analyzed as a laboratory control sample for each batch of samples.

Under carefully designed experimental conditions, a sufficient accuracy and precision was demonstrated. The precision of analysis for most of the elements was $\sim 5 \%$ relative standard deviation. The accuracy of the analysis was compared within $\pm 15 \%$ of the wet chemistry analysis results for 10 elements $(\mathrm{Al}, \mathrm{B}, \mathrm{Ca}, \mathrm{Fe}, \mathrm{Li}, \mathrm{Mg}, \mathrm{Na}, \mathrm{Ni}, \mathrm{Si}$, and Ti) for a Hanford tank waste sample from 241-AY-102/C-106 (AY-102). The comparisons for $\mathrm{P}, \mathrm{Mn}, \mathrm{Zn}$, and $\mathrm{Cr}$ were higher than the 10 elements above. Elements $\mathrm{Cd}, \mathrm{K}, \mathrm{Sr}, \mathrm{Zr}$, and $\mathrm{Sb}$ were not detected because of their low abundance in the AY-102 sample. The accuracy of S cannot be assessed because of the uncertainty in the reported value. Due to the lack of sufficient calibration data for Th, Tl, and $\mathrm{U}$, the data for these elements should be considered qualitative. The TAT study evaluated total time required from sample preparation (conversion of sludge to a glass puck) to data reduction. The sample preparation time was less than 2 hours. The TAT for sample analysis included two process batches: one batch of four AY-102 samples and another batch of eight AY-102 samples. Both batches included blank and quality control samples. The analysis time for both batches was less than 5 hours. Data reduction was completed in less than 2 hours. The TAT from receipt of 
sample, sample preparation, and data processing was shown to be less than 9 hours for each batch.

The results obtained from the analysis of the radioactive AY-102 glass are satisfactory. The adaptation of the developed method (for hot cell testing using radioactive samples) successfully demonstrated the acceptance of the selected technology for meeting the rapid TAT requirements for monitoring the vitrification process. The LA-ICP-AES results were verified with wet chemistry data. The waste generated from the LA-ICP-AES method is significantly less when compared to conventional dissolution methods. 


\section{Table of Contents}

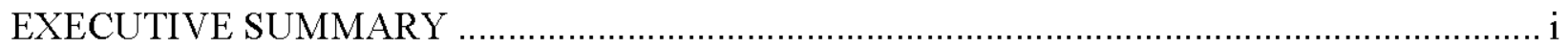

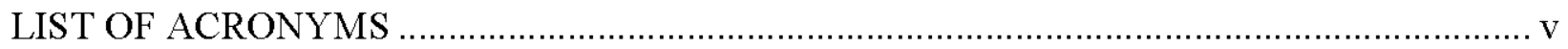

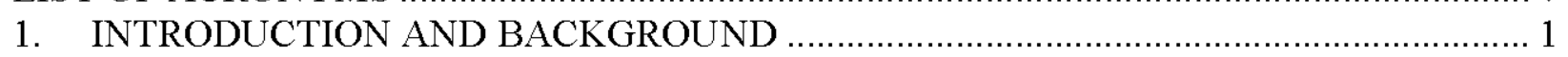

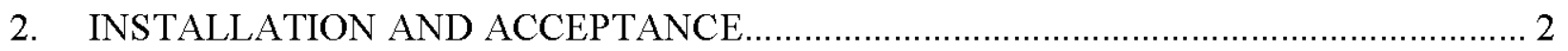

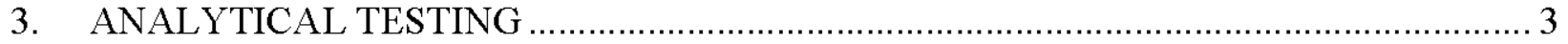

3.1 DEVELOPMENT AND OPTIMIZATION OF THE GLASS FUSION

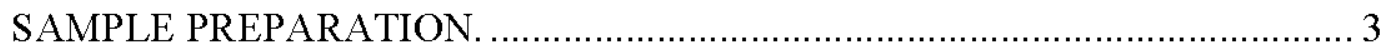

3.2 LA-ICP-AES TEST PARAMETERS AND ANALYSIS ............................... 4

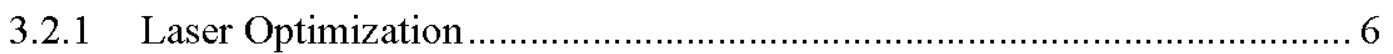

3.2.2 Inductively Coupled Plasma-Atomic Emission Spectroscopy Parameters ........................................................................ 8

3.2.3 Inductively Coupled Plasma-Atomic Emission Spectroscopy Emission Lines .......................................................................................... 8

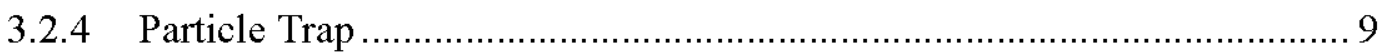

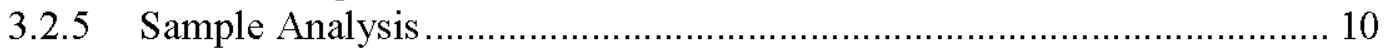

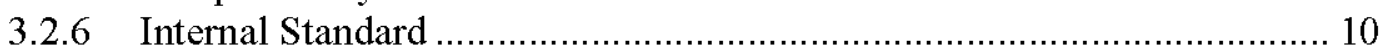

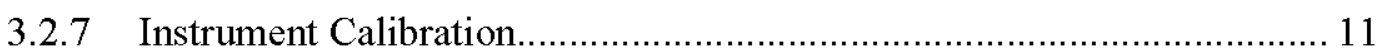

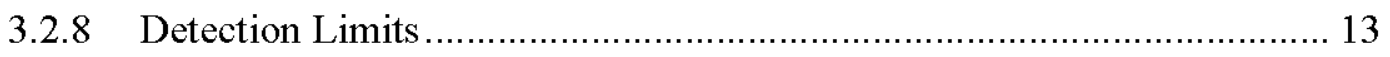

3.2.9 Radioactive Glass Sample and Analysis Sequence............................ 14

3.2.10 Precision and Accuracy ............................................................. 15

3.2.11 Operator and Day Variability ....................................................... 18

3.2.12 Turnaround Time Study …...................................................... 18

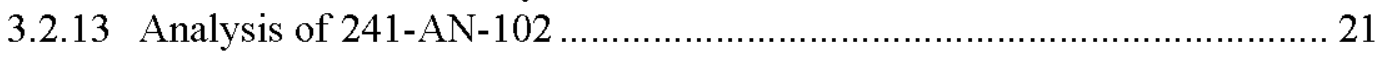

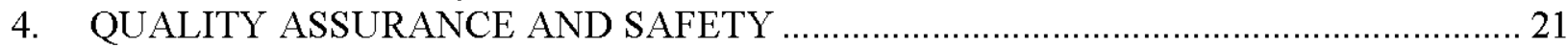

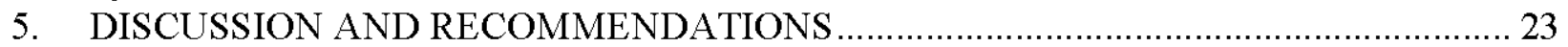

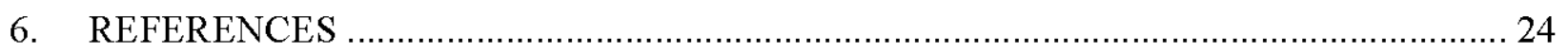

\section{Appendixes}

\section{NOTE: Appendixes A through $\mathrm{H}$ are for Official Use Only (OUO) and are not included} with this report but can be accessed through the OUO process.

APPENDIX A Waste Treatment and Immobilization Plant/222-S Laser

Ablation Task Plan; CH2M-0600207 REISSUE ................................... A-i

APPENDIX B Hold Points Defined in the Waste Treatment and Immobilization

Plant/222-S Laser Ablation Task Plan (CH2M-0600207).................... B-i

APPENDIX C Waste Treatment and Immobilization Plant Certificate of

Conformance........................................................................

APPENDIX D Photographs of System Installation ............................................... D-i

APPENDIX E $\quad$ Work Package for LA-ICP-AES Installation (step 1 and step 2) ..............i

APPENDIX F General LA-ICP-AES Analytical Procedure ATS-LT-505-105 ..............F-i 
APPENDIX G General Operation and Maintenance Procedure ATS-LO-161-183 ........ G-i

APPENDIX H Copy of LA-ICP-AES Data Printouts .............................................. H-i

\section{List of Figures}

Figure 1. Shipping Damage to Assembly Bolts on Bottom of Glove Box

\section{List of Tables}

Table 1. Sequential Steps for Preparing Glass Coupons in 11A3 Hot Cell 4

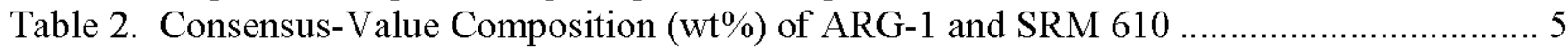

Table 3. Stability of Signal Using Raster Sample Pattern Over Time (SRM 610).................... 7

Table 4. Laser Operating Parameters ............................................................................. 7

Table 5. Inductively Coupled Plasma-Atomic Emission Spectroscopy Operating Parameters.... 8

Table 6. Inductively Coupled Plasma-Atomic Emission Spectroscopy Wavelength Selection .... 9

Table 7. Effect of Particle Trap on the Precision of Analysis ................................................. 9

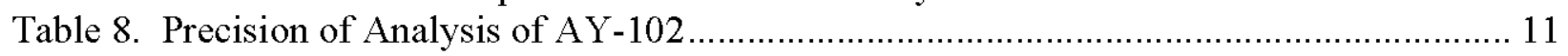

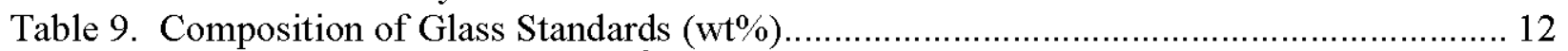

Table 10. Coefficients of Regression $\left(\mathrm{r}^{2}\right)$ from Calibration Curves ..................................... 13

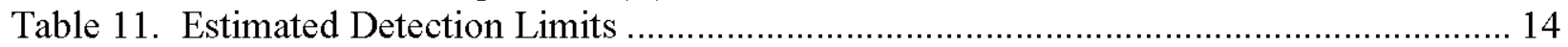

Table 12. Reported and Analyzed Concentrations (wt\%) in ARG-1 Glass Coupon .................. 16

Table 13. Analyzed and Reported Elemental Concentrations (wt\%) in AY-102 Glass Coupon 17

Table 14. Analyzed and Reported Concentrations (wt \%) of Th, Tl, and U in AY-102 Glass .... 18

Table 15. Elemental Concentration (wt \%) of AY-102 Analyzed by Different Operators on

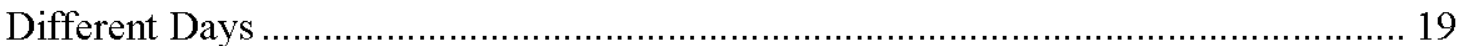

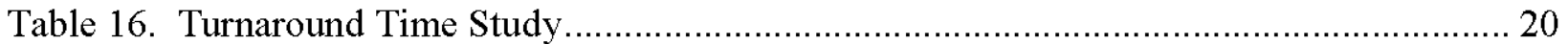

Table 17. LA-ICP-AES and ICP-AES Method Comparison (wt\%).................................... 22 


\section{LIST OF ACRONYMS}

APD

ARG-1

ATL

AY-102

HLW

ICP-AES

LA-ICP-AES

LCS

PNNL

RSD

SRNL

TAT

UV

WRPS

wt $\%$

WTP
Analytical Process Development

Analytical Reference Glass (ARG-1 "Glass standard 1")

Advanced Technologies and Laboratories International, Inc.

Refers to the waste sampled form tank 241-AY-102 after the contents of tank 241-C-106 was transferred to 241-AY-102. Also referred to as 241-AY-102/C-106

high-level waste

inductively coupled plasma-atomic emission spectroscopy

laser ablation-inductively coupled plasma-atomic emission spectroscopy (also referred to as laser ablation inductively coupled plasma atomic emission spectrometry)

laboratory control sample

Pacific Northwest National Laboratory

relative standard deviation

Savannah River National Laboratory

turnaround time

ultraviolet

Washington River Protection Solutions LLC

weight percent

Waste Treatment and Immobilization Plant 


\section{INTRODUCTION AND BACKGROUND}

This report documents the completion of the study to determine the applicability of laser ablation-inductively coupled plasma-atomic emission spectroscopy (LA-ICP-AES) glove-box technology as a primary process control analytical technique supporting the Hanford Waste Treatment and Immobilization Plant (WTP). The following appendixes are included with this report:

Appendix A Waste Treatment and Immobilization Plant/222-S Laser Ablation Task Plan; CH2M-0600207 REISSUE

Appendix B Hold Points Defined in the Waste Treatment and Immobilization Plant/ 222-S Laser Ablation Task Plan (CH2M-0600207)

Appendix C Waste Treatment and Immobilization Plant Certificate of Conformance

Appendix D Photographs of System Installation

Appendix E Work Package for LA-ICP-AES Installation (step 1 and step 2)

Appendix F General LA-ICP-AES Analytical Procedure ATS-LT-505-105

Appendix G General Operation and Maintenance Procedure ATS-LO-161-183

Appendix H Copy of LA-ICP-AES Data Printouts

This task represents Phase II of the WTP method development study following the completion of Phase I (WSRC-TR-2005-00260, The Development of Laser Ablation-Inductively Coupled Plasma-Atomic Emission Spectroscopy for the Analysis of Hanford High Level Waste: Phase I, and WTP-RPT-140, Laser Ablation/ICP-AES Time Study) for the implementation of the LA-ICP-AES method in the WTP laboratory. This work included investigating the configuration and efficiency of the system for use in the Hanford WTP process support laboratory. This task was completed by Washington River Protection Solutions LLC (WRPS) with the transition to the Tank Operations Contract on October 1, 2008.

Analytical characterization techniques must be robust to process compositional variations and must be capable of meeting the specified sample analytical time available to maintain process design production rates and produce acceptable glass. This investigation was to verify the required sample turnaround time (TAT) of less than 9 hours is achievable using the LA-ICP-AES hot-cell glove-box prototype system on an actual high-level waste (HLW) sample. The method adaptation and testing was studied to determine if LA-ICP-AES technology can provide sufficient accuracy and precision to determine melter feed chemistries.

The work reported here involves (a) installation and testing of a WTP procured LA-ICP-AES glove-box system properly configured in the adjacent hot cell for remotely ablating HLW samples, and (b) adaptation of the Phase I developed LA-ICP-AES method to routine operational requirements. In addition, the adapted Phase I methodology must demonstrate acceptable TAT and meet the requirements of determinative methods for elemental analysis. This work addressed the scope defined by Memorandum of Agreement CHG-BNI-2001; Task 
Order 2005-003; ATS-MP-1027, Management Plan for Waste Treatment Plant Project Work Performed by Analytical Technical Services, and the associated statement of work. This report covers the task descriptions for system installation, subsequent testing of developed methodology, and establishing TAT for the analytical process. The purpose of the study was to demonstrate the feasibility of implementing the LA-ICP-AES technology for WTP laboratory monitoring of the vitrification process.

\section{INSTALLATION AND ACCEPTANCE}

The installation of the LA-ICP-AES was performed under Work Package 2S-04-02382. A copy of this work package and the supporting documentation is attached in Appendix E step 1 and Appendix E step 2. Step 1 of the work package covers site preparation up to receipt of the LA-ICP-AES from the vendor. Step 2 covers the installation and vendor testing. The development of the site installation work instructions and some site pre-acceptance preparations were conducted prior to receipt of and acceptance of the vendor's equipment. After vendor acceptance testing was conducted at the vendor's facility in Omaha, Nebraska, the equipment was shipped to the WTP Marshaling Yard and then transferred to the 222-S Laboratory on April 8, 2008.

On receipt at the 222-S Laboratory, shipping damage was noted on the assembly bolts on the bottom of the glove box (see Figure 1). As shown in Figure 1, the mounting bolts were bent slightly out of alignment. It was noted that the crating of the glove box allowed the unit to freely float within the shipping crate. At the time of receipt, the damage noted was not severe enough to prevent installation. Later, during installation, additional damage was discovered to the computer table and torch positioning apparatus within the glove box that was not apparent at the loading dock when the equipment was received. While there was no evident damage to the edges of the computer table, the table top was split across the width in the center of the table.

Figure 1. Shipping Damage to Assembly Bolts on Bottom of Glove Box

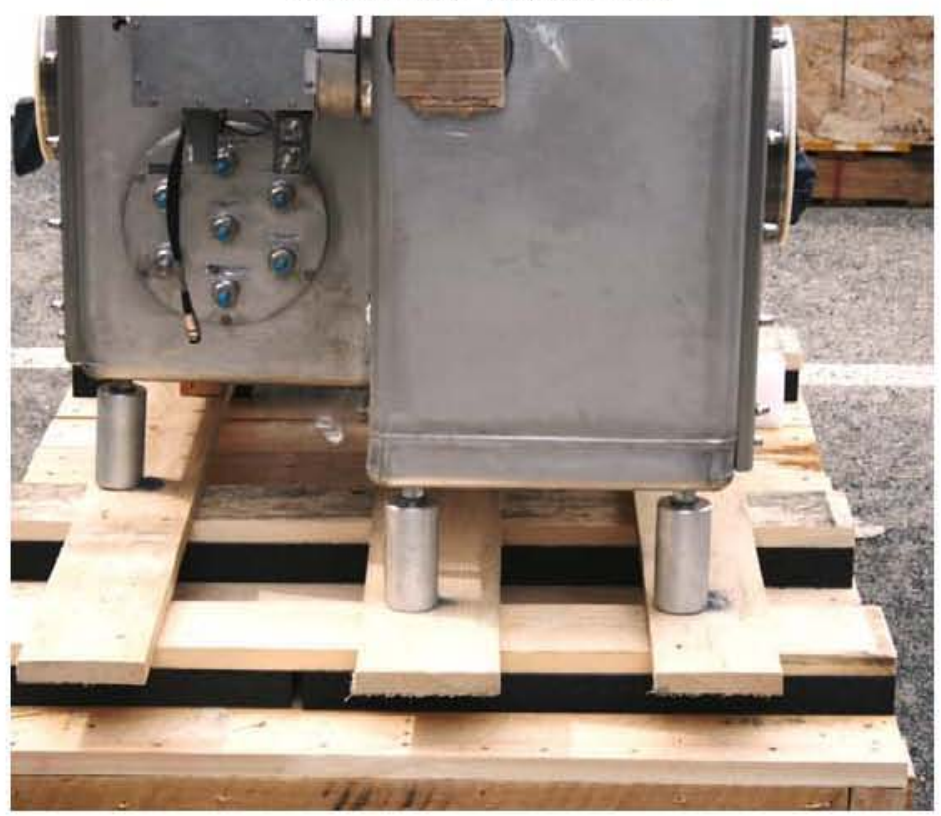


The onsite installation continued immediately on receipt and acceptance of the equipment. Photographs of the installation are attached in Appendix D of this report. The equipment was assembled by the 222-S Facility Maintenance and plant personnel including modifications to utility feeds. No major issues were encountered during installation, although the damage to the torch positioning apparatus delayed the vendor acceptance test while troubleshooting and repair of this part of the LA-ICP-AES was accomplished by the vendor.

\section{ANALYTICAL TESTING}

\subsection{DEVELOPMENT AND OPTIMIZATION OF THE GLASS FUSION SAMPLE PREPARATION.}

This task included development of a glass fusion procedure that was applicable to the hot cell environment. Glass coupons prepared from tank simulant were produced in accordance with test plan 7S110-MFM-07-096, "Preparation of Glass Coupons from Tank Simulant." Developmental work was performed using "Early Feed Chemical Simulant" identified as FY-06-SS Early. The guidelines for the production of the glass coupons included the following constraints:

a. Each coupon shall contain less than $3 \mathrm{~g}$ of tank waste solids.

b. Glass formers and temperature shall be achievable in the hot cell environment.

c. The procedure used would be simple enough to perform remotely.

d. The fusion of the glass would not produce an unacceptable heat load on the hot cell.

Coupon size consisted of the following:

a. Diameter: $25 \mathrm{~mm}-35 \mathrm{~mm}$ (optimum $30 \mathrm{~mm}$ ); smaller sizes can be used with an adapter.

b. Thickness: $1.6 \mathrm{~mm}-6 \mathrm{~mm}$ (optimum $4 \mathrm{~mm}$ ).

c. Broken shards will be usable with an adapter.

Compliance with the above guidelines was achieved. A 1 to 4 ratio of sample and flux was used to prepare the glass coupon. Sample weight used was approximately $1.67 \mathrm{~g}$. Glass coupons measured during the development period produced a coupon thickness from $3.06 \mathrm{~mm}$ to $4.36 \mathrm{~mm}$ and diameters of $27.52 \mathrm{~mm}$ to $30.71 \mathrm{~mm}$.

A borate fusion technique was used to prepare glass coupons in 11A hot cell. A radioactive sample was placed in a crucible and transferred to the muffle furnace at $200{ }^{\circ} \mathrm{C}$ to obtain a dried slurry sample. The dried slurry sample was mixed in an approximate 1 to 4 ratio of lithium metaborate/lithium tetraborate flux comprised of $34 \%$ lithium metaborate and $66 \%$ lithium tetraborate. The mixture was then spiked with germanium oxide as an internal standard. Lithium bromide was added as a non-wetting agent to prevent the flux from sticking to the crucible and mold when removed. The dried radioactive waste sample and flux were then placed in a $95 \%$ platinum $5 \%$ gold crucible and placed in the muffle furnace at $1100{ }^{\circ} \mathrm{C}$ with constant agitation. The $30-\mathrm{mm}$ mold was also placed in the furnace at this time to ensure it was at the 
proper temperature to accept the glass once fused. A SK-600 reciprocating shaker set at 60 revolutions per minute for 15 minutes was used to ensure that the sample completely dissolved into the molten flux. After this step was completed, the shaker was turned off; the melt was poured into a heated $30-\mathrm{mm}$-diameter platinum/gold mold, and allowed to cool to $500{ }^{\circ} \mathrm{C}$ in the muffle furnace with the door open prior to placing the glass sample in a desiccator to complete the cooling period. The complete fusion procedure resulted in a TAT of $1 \mathrm{hr}$ 45 minutes. This procedure is fully defined in Appendix F.

Table 1 represents sequential steps and the time taken to prepare a glass coupon in the hot cell. To ensure the procedure was safe in the hot cell environment, thermocouples were placed in the hot cell to monitor the impact of the heat load from this method. The temperature close to the glass windows did not increase more than $1{ }^{\circ} \mathrm{C}$ during the performance of this activity.

Table 1. Sequential Steps for Preparing Glass Coupons in 11A3 Hot Cell

\begin{tabular}{|c|c|c|}
\hline Step & Preparation Sequence & $\begin{array}{l}\text { Duration } \\
\text { (minutes) }\end{array}$ \\
\hline 1 & The balance is tared & 1 \\
\hline 2 & A sample weight of slurry and crucible is obtained & 3 \\
\hline 3 & Sample drying at $200^{\circ} \mathrm{C}$ & 30 \\
\hline 4 & The crucible is removed from the muffle furnace & 1 \\
\hline 5 & $\begin{array}{l}\text { The crucible is cooled for } 30 \text { minutes, and the muffle } \\
\text { furnace temperature is taken from } 200^{\circ} \mathrm{C} \text { to } 1100^{\circ} \mathrm{C}\end{array}$ & 30 \\
\hline 6 & $\begin{array}{l}\text { The dried slurry sample, flux, and lithium bromide is placed } \\
\text { into the crucible and reweighed (the internal standard is } \\
\text { added here) }\end{array}$ & 2 \\
\hline 7 & $\begin{array}{l}\text { The crucible is placed in the furnace for fusion and shaker is } \\
\text { started }\end{array}$ & 15 \\
\hline 8 & $\begin{array}{l}\text { The crucible is removed from the furnace and the melt } \\
\text { poured into the mold. The furnace door remains open, The } \\
\text { furnace is shut off, and the melt allowed to cool to } \sim 500^{\circ} \mathrm{C}\end{array}$ & 7 \\
\hline 9 & At $\sim 400^{\circ} \mathrm{C}$ the mold is removed from the muffle furnace & 1 \\
\hline 10 & The mold is placed in the desiccator to cool & 15 \\
\hline 11 & The glass coupon is removed from the mold & \\
\hline & Total time to prepare glass coupon in hot cell & 1 hour 45 minutes \\
\hline
\end{tabular}

\subsection{LA-ICP-AES TEST PARAMETERS AND ANALYSIS}

The test scope utilized the method developed in parallel studies conducted at Savannah River National Laboratory (SRNL) and Pacific Northwest National Laboratory (PNNL). The instrument model and configurations used in those two studies were different. Therefore the optimization of the LA-ICP-AES prototype system was necessary for reproducible, reliable results. The instrument system optimization was performed using two glass coupons, SRM 610 and ARG-1, which contained a significant number of analytes of interests. Optimization discussions of the components are presented in the following section. The consensus-value 
compositions of SRM 610 (GeoReM, Max-Planck Institute Reference Materials ${ }^{1}$ ) and ARG-1 [24590-101-TSA-W000-0004-158-00002 (WTP-RPT-140), Laser Ablation Study for High Level Waste and Melter Feed Characterization] are summarized in Table 2.

Table 2. Consensus-Value Composition (wt $\%$ ) of ARG-1 and SRM 610

\begin{tabular}{|c|c|c|}
\hline Elements & ARG-1 & SRM-610 \\
\hline $\mathrm{Al}$ & 2.47 & 1.0812 \\
\hline $\mathrm{B}$ & 2.65 & 0.0356 \\
\hline $\mathrm{Ca}$ & 1.01 & 8.165 \\
\hline $\mathrm{Cd}$ & - & 0.0259 \\
\hline $\mathrm{Cr}$ & 0.068 & 0.0405 \\
\hline $\mathrm{Fe}$ & 9.810 & 0.0458 \\
\hline $\mathrm{K}$ & 2.220 & 0.0486 \\
\hline $\mathrm{Li}$ & 1.48 & 0.0485 \\
\hline $\mathrm{Mg}$ & 0.525 & 0.0465 \\
\hline $\mathrm{Mn}$ & 1.470 & 0.0485 \\
\hline $\mathrm{Na}$ & 8.31 & 9.941 \\
\hline $\mathrm{Ni}$ & 0.817 & 0.0459 \\
\hline $\mathrm{P}$ & 0.118 & 0.0343 \\
\hline $\mathrm{S}$ & - & 0.0693 \\
\hline $\mathrm{Sb}$ & - & 0.0369 \\
\hline $\mathrm{Si}$ & 22.3 & 32.72 \\
\hline $\mathrm{Sr}$ & 0.0034 & 0.0516 \\
\hline $\mathrm{Th}$ & - & 0.0457 \\
\hline $\mathrm{Ti}$ & 0.701 & 0.0434 \\
\hline $\mathrm{Tl}$ & - & 0.0061 \\
\hline $\mathrm{U}$ & - & 0.0462 \\
\hline $\mathrm{Zn}$ & 0.0161 & 0.0456 \\
\hline $\mathrm{Zr}$ & 0.104 & 0.0440 \\
\hline
\end{tabular}

- Information is not reported

Optimization of the system required tuning of both the laser and the inductively coupled-atomic emission spectrometry (ICP-AES) units. The main goal was to achieve a good signal to background ratio for most of the analytes of interest. The laser ablates the sample to produce particles. The ablated particles are then transported in an argon stream to the plasma torch of ICP-AES where excitation of analytes takes place. The element specific wavelengths (lines) are measured by the ICP-AES spectrophotometer to quantify elements.

\footnotetext{
${ }^{\mathbf{1}}$ GeoReM is a Max-Planck-Institute database for reference materials of geological and environmental interest, such as rock powders, synthetic, and natural glasses, as well as mineral, isotopic, biological, river water, and seawater reference materials.
} 
Both laser ablation and ICP-AES parameters are important to achieve high quality data in accordance with the following references:
a. DOE/RL-96-68, Hanford Analytical Services Quality Assurance Requirements Documents (HASQARD).
b. ATS-MP-1032, 222-S Laboratory Quality Assurance Plan.
c. PL-24590 QA00001, Quality Assurance Project Plan for Testing Programs Generating Environmental Regulatory Data.
d. TFC-PLN-02, Quality Assurance Program Description.
e. TFC-PLN-30, CH2M HILL Analytical Technical Services Quality Assurance Program
Plan.

Section 3.2.1 addresses specific parameters tested and used for these studies.

\subsubsection{Laser Optimization}

The efficiency of particle generation is dependent on the laser parameters, i.e., beam energy, repetition rate, spot size, and scan rate. The system is equipped with a $266-\mathrm{nm}$ ultraviolet (UV) laser beam, which is considered suitable for bulk analysis. It has been found that using a laser with output in the UV region of the spectrum, heating of the bulk sample is minimal and therefore vaporization of volatile constituents from the sample is avoided. Energy settings of 5\%-100\% can be chosen, and the energy at the sample can be measured by a built-in energy meter. For optimization an energy setting of $100 \%$ was used yielding energy of $8 \mathrm{~mJ}$ at the sample.

The spot size governs the amount of ablated particles produced. Larger beam sizes create larger craters and generate more particles. Various scientific articles on laser ablation suggest beam sizes ranging from $200 \mu \mathrm{m}-400 \mu \mathrm{m}$ :
a. "Selection of Internal Standards for the Determination of Major and Minor Elements in Silicate Rocks and Limestones by Laser Ablation Inductively Coupled Plasma Atomic Emission Spectrometry" (Kanicky and Mermet 1997).
b. "Use of Internal Standardization to Compensate for a Wide Range of Absorbance in the Analysis of Glasses by UV Laser Ablation Inductively Coupled Plasma Atomic Emission Spectrometry" (Kanicky et al. 1998).
c. "Analysis of glass by UV laser ablation inductively coupled plasma atomic emission spectrometry. Part 1. Effects of the laser parameters on the amount of ablated material and the temporal behaviour of the signal for different types of laser" (Ducreux-Zappa and Mermet 1996).

However, the current laser system has a fixed beam diameter to produce a spot size of $150 \mu \mathrm{m}$ and generates enough particles to provide adequate signal on Hanford tank waste samples. 
A typical repetition rate of $20 \mathrm{~Hz}$ was chosen for the best results based on the results of other studies, including SRNL and PNNL. The best signal and precision were obtained in the earlier studies using the repetition rate of $20 \mathrm{~Hz}$.

The instrument options included using spot, line, and rastering sample patterns. A single spot will not give a steady signal over the duration of the analysis. Similarly, if the laser shots are fired on the same line repeatedly, the decrease of signal is obvious before the analysis is completed. Therefore, both spot and line patterns were deemed unsuitable. Instead a raster pattern was chosen because a representative sampling was desired to achieve reproducible results. A sufficient distance $(\sim 200 \mu \mathrm{m})$ was maintained between pattern lines to ensure that on the beam's second path, it would not cross over the original scanned line or debris from the first pass.

The scan rate was adjusted in conjunction with spot size. The available surface area on the sample and analysis time plays important roles in setting a scan speed. In this study a raster pattern was used that required ample surface on the sample during analysis. Although the instrument gave a choice of settings from $10 \mu \mathrm{m} / \mathrm{s}$ to $1000 \mu \mathrm{m} / \mathrm{s}$, a $25 \mu \mathrm{m} / \mathrm{s}$ scan rate was chosen for best results. This utilized (ablated) an area of approximately $8.30 \mathrm{~mm}^{2}$ during a typical analysis.

The results presented in Table 3 utilized the rastering sample pattern on SRM 610 glass. It is evident from the data that the drift was within acceptable range and the raster pattern suits well for achieving a steady-state signal.

Table 3. Stability of Signal Using Raster Sample Pattern Over Time (SRM 610)

\begin{tabular}{|c|c|c|c|c|c|c|c|c|c|c|}
\hline \multirow{2}{*}{$\begin{array}{c}\text { Element and } \\
\text { Wavelength } \\
(\mathrm{nm})\end{array}$} & \multicolumn{9}{|c|}{ Concentration $(\mu \mathrm{g} / \mathrm{g})$} & \multirow[b]{2}{*}{$\begin{array}{c}\% \\
\text { RSD } \\
\end{array}$} \\
\hline & $0 \mathrm{hr}$ & $\begin{array}{c}0 \mathrm{hr} \\
5 \mathrm{~min}\end{array}$ & $\begin{array}{c}0 \mathrm{hr} \\
30 \mathrm{~min}\end{array}$ & $\begin{array}{c}0 \mathrm{hr} \\
45 \mathrm{~min}\end{array}$ & $1 \mathrm{hr}$ & $\begin{array}{c}1 \mathrm{hr} \\
15 \mathrm{~min}\end{array}$ & $\begin{array}{c}1 \mathrm{hr} \\
30 \mathrm{~min}\end{array}$ & $\begin{array}{c}1 \mathrm{hr} \\
45 \mathrm{~min}\end{array}$ & $2 \mathrm{hr}$ & \\
\hline $\mathrm{Pb} 220.353$ & 342.1 & 433.6 & 436.1 & 452.8 & 439.8 & 434.2 & 450.4 & 428.3 & 427.6 & 2.42 \\
\hline $\mathrm{Cd} 214.441$ & 240.5 & 237.8 & 240.6 & 251.5 & 250.0 & 245.3 & 256.8 & 229.7 & 230.1 & 3.85 \\
\hline Cr 359.349 & 421.7 & 405.7 & 383.6 & 426.8 & 414.6 & 366.9 & 367.3 & 372.0 & 378.8 & 6.15 \\
\hline $\mathrm{Cu} 224.700$ & 312.7 & 449.6 & 386.4 & 384.1 & 360.9 & 361.0 & 401.2 & 321.1 & 312.0 & 12.17 \\
\hline La 429.655 & 438.2 & 457.6 & 431.0 & 441.6 & 438.0 & 431.1 & 447.4 & 421.3 & 407.4 & 2.38 \\
\hline
\end{tabular}

$\mathrm{RSD}=$ relative standard deviation

The final operating parameters of laser ablation are provided in Table 4 .

Table 4. Laser Operating Parameters

\begin{tabular}{|l|l|}
\hline Laser wavelength & $266 \mathrm{~nm}$ UV \\
\hline Spot size $(\mu \mathrm{m})$ & 150 (largest aperture) \\
\hline Laser power & $100 \%$ setting $(\approx 8 \mathrm{~m} \mathrm{~J}$ at sample) \\
\hline Rate $(\mathrm{Hz})$ & 20 \\
\hline Method & Raster scan \\
\hline Scan rate & $25 \mu \mathrm{m} / \mathrm{sec}$ (software setting of 25$)$ \\
\hline
\end{tabular}




\subsubsection{Inductively Coupled Plasma-Atomic Emission Spectroscopy Parameters}

The LA-ICP-AES glove box prototype system integrated the laser unit to the HJY Ultima ${ }^{2}$ ICP-AES. The optimization of the ICP-AES included the adjustment of radio frequency power and various argon gas flows (i.e., plasma, coating, auxiliary, and nebulizer). The nebulizer argon gas flow rate was also monitored to check for any fluctuation during the analysis. Initially, the specific operating conditions were set to the parameters utilized in the factory and site acceptance tests. The ICP-AES was allowed to warm up normally for 1 hour prior to analysis. In the WTP laboratory the instrument will be kept on all the time; therefore, no warm-up time will be required. A 90 -second delay from the onset of the LA to ICP-AES signal processing was allowed for the stabilization in the plasma to occur. The peak integration time of 5 seconds was used for each analyte. The SRM 610 was ablated and the ICP-AES conditions were optimized to achieve optimum signal to background ratios for the analytes of interest. A summary of ICP-AES operating parameters is provided in Table 5. The argon flow to nebulizer was restricted in original instrument settings. This restriction was removed, and a gas flowmeter was installed to monitor actual nebulizer flow that allowed varying and optimizing the nebulizer gas flow during the optimization process.

\section{Table 5. Inductively Coupled Plasma-Atomic Emission Spectroscopy Operating Parameters}

\begin{tabular}{|l|l|}
\hline Power (W) & 1000 \\
\hline Plasma gas (L/minute) & 12 \\
\hline Coating gas (L/minute) & G1-0.2 \\
\hline Auxiliary gas (L/minute) & 0 \\
\hline Nebulizer pressure (bar) & 3.73 \\
\hline Nebulizer flow (L/minute) & 0.7 \\
\hline Stabilization time (seconds) & 90 \\
\hline
\end{tabular}

\subsubsection{Inductively Coupled Plasma-Atomic Emission Spectroscopy Emission Lines}

The HJY software has many lines available for each element, and factors such as detection limit, relative sensitivity, spectral interference, and signal to background ratios aid in selecting the best emission line for analysis of any given element. In a complex matrix where the possibility of interferences exists, choosing an interference-free line becomes extremely important. Therefore, analyzing multiple lines for a single element is advantageous to ensure valid data. Table 6 shows the lines that were chosen for this study. The selection was made on the basis of the vendor acceptance test and site acceptance test data. Most of the lines (except Al, B, Ca, P, and S) used in these tests were above $200 \mathrm{~nm}$ and did not require nitrogen purge of the ICP-AES optics. For $\mathrm{Al}, \mathrm{B}, \mathrm{Ca}$, and $\mathrm{P}$, alternate lines above $200 \mathrm{~nm}$ were also selected.

\footnotetext{
${ }^{\mathbf{2}}$ HJY Ultima is a registered trademark of HORIBA Jobin Yvon Inc., Edison, New Jersey.
} 


\subsubsection{Particle Trap}

Laser ablation can generate the particles of all sizes and shapes. Because larger particles may lead to erratic signal and poor sensitivity, they are not suitable for introduction into the plasma. The larger particles can also precipitate on the walls of the sample transfer tubing to introduce contamination. Therefore, a particle trap was introduced in the sample transfer line to trap larger particles. The presence of an in-line trap required increasing the purge time and also pre-ablation time. It was interesting to note (Table 7) that the particle trap improved the precision of the analysis. However, it had very little effect on the sensitivity.

Table 6. Inductively Coupled Plasma-Atomic Emission Spectroscopy Wavelength Selection

\begin{tabular}{|c|c|}
\hline Element & Wavelength (nm) \\
\hline $\mathrm{Al}$ & $167.018 ; 226.346$ \\
\hline $\mathrm{B}$ & $181.724 ; 249.773$ \\
\hline $\mathrm{Ca}$ & $183.958 ; 317.933$ \\
\hline $\mathrm{Cd}$ & 226.502 \\
\hline $\mathrm{Cr}$ & 205.571 \\
\hline $\mathrm{Fe}$ & 259.940 \\
\hline $\mathrm{K}$ & 766.490 \\
\hline $\mathrm{Li}$ & 670.792 \\
\hline $\mathrm{Mg}$ & 279.553 \\
\hline $\mathrm{Mn}$ & 257.610 \\
\hline $\mathrm{Na}$ & 589.592 \\
\hline $\mathrm{Ni}$ & 231.096 \\
\hline $\mathrm{P}$ & $178.221 ; 213.618$ \\
\hline $\mathrm{S}$ & 181.972 \\
\hline $\mathrm{Sb}$ & 206.833 \\
\hline $\mathrm{Si}$ & 252.411 \\
\hline $\mathrm{Sr}$ & 215.284 \\
\hline $\mathrm{Th}$ & 323.812 \\
\hline $\mathrm{Ti}$ & 323.904 \\
\hline $\mathrm{Tl}$ & 276.787 \\
\hline $\mathrm{U}$ & 311.162 \\
\hline $\mathrm{Zn}$ & 206.200 \\
\hline $\mathrm{Zr}$ & 343.823 \\
\hline
\end{tabular}

Table 7. Effect of Particle Trap on the Precision of Analysis

\begin{tabular}{|c|c|c|}
\hline Element & $\begin{array}{c}\text { \% RSD without } \\
\text { Particle Trap }\end{array}$ & $\begin{array}{c}\text { \% RSD with } \\
\text { Particle Trap }\end{array}$ \\
\hline $\mathrm{Pb} \mathrm{220.353}$ & 4.76 & 0.86 \\
\hline $\mathrm{Cd} 214.441$ & 4.04 & 0.83 \\
\hline $\mathrm{Cr} \mathrm{359.349}$ & 2.83 & 1.13 \\
\hline $\mathrm{Cu} 224.700$ & 3.85 & 0.72 \\
\hline $\mathrm{La} \mathrm{429.655}$ & 2.13 & 0.90 \\
\hline
\end{tabular}




\subsubsection{Sample Analysis}

The work performed at SRNL used a pre-ablation time of 45 seconds. The pre-ablation time ensures that the signal is at steady state prior to signal integration. The sample cell of this instrument is larger than laser ablation cells used in commercially available laser ablation instruments. This study not only concentrated on pre-ablation time but also optimized the gas purge time and wash time. The tube length to connect the laser sample cell to the ICP-AES torch was $22 \mathrm{ft}$. Both the large sample cell and long sample transfer tubing required purging of system and pre-ablation for a longer time to ensure that (a) the wash time between samples was sufficient to eliminate the cross contamination, (b) the purge gas flushed air from the laser ablation cell to an exit away from the plasma, and (c) the pre-ablation time was sufficient to stabilize the signal. Initially the purge time was set to 45 seconds, but when the sample trap was added to the transfer line, this time was increased to 90 seconds to account for the additional volume added to the system. The pre-ablation time was also increased to 90 seconds. While conducting these studies, the decay of the signal after the laser stopped ablating was also monitored. This was measured to determine the time needed to clear the sample out of the transfer tubing between analyses, thereby eliminating any possible sample contamination. The argon sweep gas was in bypass mode during coupon loading. After the coupon was placed in the laser ablation cell, the laser sample cell was purged for 90 seconds, and the argon flow was switched online to the ICP-AES. At this time the laser began ablating and sample ablation occurred. Argon flow through the sample cell and ICP-AES continued during the 90 -second ICP-AES delay (pre-ablation) time, for a total sample cell purge of 3 minutes prior to ICP-AES data acquisition. The raster pattern established via computer control was used to ablate each sample.

Another parameter of interest was the number of replicates and integration time for each analyte. The total time of analysis for each wavelength varied depending on the ICP-AES used, specifically the integration time chosen. Since this ICP-AES is a sequential instrument, it measures analytes individually in sequence and takes more time compared to the simultaneous instrument used in studies at SRNL and PNNL. Increased replicates and integration time added to each element increased total measurement time. The data presented in this report utilized a 5 -second integration time and three replicates for each analyte that yielded acceptable precision (Table 8).

\subsubsection{Internal Standard}

Laser ablation is different from wet analysis in that matrix matched calibration standards are not always available for analysis of wide variety matrix samples. However, use of an internal standard helps to compensate for the differences in ablation efficiencies of unmatched samples and calibration standards. Any element that resembles the behavior of the analyte of interest can be used as an internal standard. It can be added externally in the same quantity to both samples and calibration standards. An element already present in the sample can also be used as an internal standard if its concentration is known or can be determined by an independent technique. In the case of external addition, the element chosen as an internal standard ideally should not be 
present in the sample, but if it is present its concentration should be known so it can be accounted for during data reduction.

Table 8. Precision of Analysis of AY-102

\begin{tabular}{|lc|c|c|c|}
\hline \multicolumn{2}{|c|}{ Element } & $\begin{array}{c}\text { Average Batch 1 } \\
\text { (\% RSD) }\end{array}$ & $\begin{array}{c}\text { Average Batch 2 } \\
\text { (\% RSD) }\end{array}$ & $\begin{array}{c}\text { Mean } \\
\text { (\% RSD) }\end{array}$ \\
\hline $\mathrm{Al}$ & 226.346 & 3.24 & 3.17 & 3.20 \\
\hline $\mathrm{B}$ & 181.724 & 3.77 & 4.16 & 3.96 \\
\hline $\mathrm{B}$ & 249.773 & 3.55 & 4.23 & 3.89 \\
\hline $\mathrm{Ca}$ & 183.958 & 6.76 & 2.94 & 4.85 \\
\hline $\mathrm{Ca}$ & 317.933 & 5.75 & 6.43 & 6.09 \\
\hline $\mathrm{Cd}$ & 226.502 & 0.87 & 0.80 & 0.83 \\
\hline $\mathrm{Cr}$ & 205.571 & 8.70 & 5.81 & 7.25 \\
\hline $\mathrm{Fe}$ & 259.940 & 3.68 & 3.35 & 3.52 \\
\hline $\mathrm{K}$ & 766.490 & 1.64 & 1.34 & 1.49 \\
\hline $\mathrm{Li}$ & 670.792 & 3.01 & 4.43 & 3.72 \\
\hline $\mathrm{Mg}$ & 279.553 & 7.52 & 12.91 & 10.22 \\
\hline $\mathrm{Mn}$ & 257.610 & 5.00 & 4.60 & 4.80 \\
\hline $\mathrm{Na}$ & 589.592 & 4.47 & 4.53 & 4.50 \\
\hline $\mathrm{Ni}$ & 231.096 & 7.24 & 7.57 & 7.41 \\
\hline $\mathrm{P}$ & 178.221 & 6.58 & 5.47 & 6.02 \\
\hline $\mathrm{P}$ & 213.618 & 5.97 & 8.53 & 7.25 \\
\hline $\mathrm{S}$ & 181.972 & 15.47 & 17.11 & 16.29 \\
\hline $\mathrm{Sb}$ & 206.833 & 1.04 & 1.01 & 1.03 \\
\hline $\mathrm{Si}$ & 252.411 & 3.77 & 5.63 & 4.70 \\
\hline $\mathrm{Sr}$ & 215.284 & 9.65 & 9.39 & 9.52 \\
\hline $\mathrm{Th}$ & 323.812 & - & - & - \\
\hline $\mathrm{Ti}$ & 323.904 & 1.02 & 1.18 & 1.10 \\
\hline $\mathrm{Tl}$ & 276.787 & - & - & - \\
\hline $\mathrm{U}$ & 311.162 & - & - & - \\
\hline $\mathrm{Zn}$ & 206.200 & 3.45 & 5.95 & 4.70 \\
\hline $\mathrm{Zr}$ & 343.823 & 21.99 & 9.22 & 15.61 \\
\hline & & & & \\
\hline
\end{tabular}

- Not analyzed

In this study, Sc was used as an internal standard. The samples and calibration standards containing 5\% Sc were prepared and tested at SRNL and were tested in Phase II work (SRNL-SCS-2005-00019, Candidates for RPP Glass Standards, May 2005 RPP Glass; SRNL-SCS-2005-00052, Measured Compositions of Candidates for WTP Glass Standards). For accurate results, an internal standard was used with all the analyzed glasses.

\subsubsection{Instrument Calibration}

The instrument was calibrated using five well characterized glasses that were prepared at SRNL (WSRC-TR-2006-00003, The Development of Laser Ablation-Inductively Coupled PlasmaAtomic Emission spectroscopy for the analysis of Hanford High level Waste: Phase II). These nonradioactive glasses were composed to serve as calibration standards, which will encompass the range of the HLW glass that is to be made at the WTP. The composition of these standards 
was confirmed by digestion and subsequent ICP-AES analysis. These glasses were spiked with Sc internal standard. The composition of the standards is given in Table 9.

Table 9. Composition of Glass Standards (wt $\%)$

\begin{tabular}{|l|c|c|c|c|c|}
\hline Element & RPP1 & RPP2 & RPP3 & RPP4 & RPP5 \\
\hline $\mathrm{Al}$ & 1.124 & 0.774 & 2.078 & 3.323 & 0.753 \\
\hline $\mathrm{B}$ & 2.709 & 1.789 & 1.544 & 1.147 & 4.554 \\
\hline $\mathrm{Ca}$ & 1.505 & 1.853 & 0.731 & 0.391 & 0.099 \\
\hline $\mathrm{Cd}$ & 0.534 & 1.628 & 1.321 & 0.394 & 0.035 \\
\hline $\mathrm{Cr}$ & 0.068 & 0.226 & 0.041 & 0.116 & 0.034 \\
\hline $\mathrm{Fe}$ & 6.524 & 3.507 & 4.970 & 2.709 & 13.741 \\
\hline $\mathrm{K}$ & 0.855 & 0.091 & 1.594 & 3.312 & 0.091 \\
\hline $\mathrm{Li}$ & 0.915 & 0.101 & 0.460 & 2.259 & 0.097 \\
\hline $\mathrm{Mg}$ & 0.540 & 1.056 & 0.828 & 0.288 & 0.024 \\
\hline $\mathrm{Mn}$ & 3.062 & 0.706 & 4.051 & - & - \\
\hline $\mathrm{Na}$ & 9.798 & 6.882 & 6.179 & 5.306 & 14.844 \\
\hline $\mathrm{Ni}$ & 1.038 & 2.059 & 0.684 & 0.299 & 0.008 \\
\hline $\mathrm{P}$ & 0.312 & 0.576 & 0.273 & 0.189 & 0.092 \\
\hline $\mathrm{Sb}$ & 0.710 & 1.971 & 1.303 & 0.459 & 0.084 \\
\hline $\mathrm{Si}$ & 16.850 & 25.803 & 19.284 & 21.587 & 17.437 \\
\hline $\mathrm{S}$ & 0.057 & 0.100 & 0.050 & 0.077 & 0.030 \\
\hline $\mathrm{Sr}$ & 1.641 & 0.170 & 3.256 & 5.763 & 0.170 \\
\hline $\mathrm{Th}$ & - & - & - & - & - \\
\hline $\mathrm{Ti}$ & 1.164 & 0.546 & 1.740 & 0.066 & 0.060 \\
\hline $\mathrm{Tl}$ & - & - & - & - & - \\
\hline $\mathrm{U}$ & - & - & - & - & - \\
\hline $\mathrm{Zn}$ & 2.384 & 0.720 & 3.264 & 0.080 & 0.800 \\
\hline $\mathrm{Zr}$ & 2.370 & 0.060 & 1.620 & 6.230 & 0.090 \\
\hline $\mathrm{Not}$ & & & & &
\end{tabular}

It has been shown in "Quality of calibration in inductively coupled plasma atomic emission spectrometry" (Mermet 1994) that using more than four calibration standards yields a better calibration curve and coefficient of regression $\left(\mathrm{r}^{2}\right)$. However, more statistical issues can develop with the use of a large number of standards. The $r^{2}$ values generated from calibration curves are presented in Table 10. The elements and wavelengths are listed in the first column. The second column indicates the $r^{2}$ values from the instrument output. In this case the instrument software calculated the $r^{2}$ values from the calibration curves generated using all five calibration standards. The data presented in this report are primarily calculated by the instrument software based on these calibration curves.

The $\mathrm{r}^{2}$ values presented in the third column are based on data using four calibration standards that generated the best calibration curves. There is a significant improvement in the $r^{2}$ values by excluding an outlier from the calibration data. It was noted that one calibration standard (RPP-2) did not have a smooth surface and visual analysis of that standard indicated some inclusions in that standard. Both sets of data are included to emphasize the importance of homogeneity and smooth surface. The poor fit for S may be attributed to its low concentration and sensitivity. For Si the poor fit may be due to clustering of calibration points. 
Table 10. Coefficients of Regression $\left(\mathbf{r}^{2}\right)$ from Calibration Curves

\begin{tabular}{|ll|c|c|}
\hline \multicolumn{2}{|c|}{$\begin{array}{c}\text { Element and } \\
\text { Wavelength (nm) }\end{array}$} & $\begin{array}{c}\text { Instrument Output } \\
\text { Five Calibration } \\
\text { Standards }\end{array}$ & $\begin{array}{c}\text { Best Fit } \\
\text { Four Calibration } \\
\text { Standards }\end{array}$ \\
\hline $\mathrm{Al}$ & 226.346 & 0.942 & 0.976 \\
\hline $\mathrm{B}$ & 181.724 & 0.949 & 0.841 \\
\hline $\mathrm{B}$ & 249.773 & 0.975 & 0.905 \\
\hline $\mathrm{Ca}$ & 183.958 & 0.973 & 0.989 \\
\hline $\mathrm{Ca}$ & 317.933 & 0.876 & 0.966 \\
\hline $\mathrm{Cd}$ & 226.502 & 0.802 & 0.933 \\
\hline $\mathrm{Cr}$ & 205.571 & 0.255 & 0.979 \\
\hline $\mathrm{Fe}$ & 259.940 & 0.944 & 0.936 \\
\hline $\mathrm{K}$ & 766.490 & 0.956 & 0.966 \\
\hline $\mathrm{Li}$ & 670.792 & 0.957 & 0.985 \\
\hline $\mathrm{Mg}$ & 279.553 & 0.830 & 0.916 \\
\hline $\mathrm{Mn}$ & 257.610 & 0.839 & 0.997 \\
\hline $\mathrm{Na}$ & 589.592 & 0.984 & 0.986 \\
\hline $\mathrm{Ni}$ & 231.096 & 0.829 & 0.946 \\
\hline $\mathrm{P}$ & 178.221 & 0.855 & 0.901 \\
\hline $\mathrm{P}$ & 213.618 & 0.722 & 0.937 \\
\hline $\mathrm{S}$ & 181.972 & 0.846 & 0.773 \\
\hline $\mathrm{Sb}$ & 206.833 & 0.719 & 0.905 \\
\hline $\mathrm{Si}$ & 252.411 & 0.728 & 0.753 \\
\hline $\mathrm{Sr}$ & 215.284 & 0.971 & 0.953 \\
\hline $\mathrm{Th}$ & 323.812 & - & - \\
\hline $\mathrm{Ti}$ & 323.904 & 0.935 & 0.996 \\
\hline $\mathrm{Tl}$ & 276.787 & - & - \\
\hline $\mathrm{U}$ & 311.162 & - & - \\
\hline $\mathrm{Zn}$ & 206.200 & 0.844 & 0.969 \\
\hline $\mathrm{Zr}$ & 343.823 & 0.929 & 0.995 \\
\hline $\mathrm{Nat}$ analyzed & & \\
\hline & & & \\
\hline
\end{tabular}

\subsubsection{Detection Limits}

Detection limits were estimated by using the lithium borate glass as the blank. A blank glass coupon was analyzed with each batch in a manner identical to the samples and the standard deviation $(\sigma)$ was estimated. The standard deviation was multiplied by three to calculate detection limits (Table 11) and converted to concentration on a wt $\%$ glass basis by dividing the instrument response by the slope of the calibration curve. These detection limits are much better than those obtained at SRNL (WSRC-TR-2005-00260 and WSRC-TR-2006-00003) using argon gas as a blank. 
RPP-RPT-39823, Rev. 0

Table 11. Estimated Detection Limits

\begin{tabular}{|c|c|c|}
\hline \multicolumn{2}{|c|}{$\begin{array}{c}\text { Element and } \\
\text { Wavelength } \\
(\mathrm{nm}) \\
\end{array}$} & \multirow{2}{*}{$\begin{array}{c}\begin{array}{c}\text { Detection Limit } \\
\text { (wt\%) }\end{array} \\
0.0127\end{array}$} \\
\hline $\mathrm{Al}$ & 226.346 & \\
\hline $\mathrm{B}$ & 181.724 & 0.0098 \\
\hline B & 249.773 & - \\
\hline $\mathrm{Ca}$ & 183.958 & 0.0156 \\
\hline $\mathrm{Ca}$ & 317.933 & 0.0040 \\
\hline $\mathrm{Cd}$ & 226.502 & 0.0019 \\
\hline $\mathrm{Cr}$ & 205.571 & 0.0009 \\
\hline $\mathrm{Fe}$ & 259.940 & 0.0277 \\
\hline $\mathrm{K}$ & 766.490 & 0.0029 \\
\hline$\overline{\mathrm{Li}}$ & 670.792 & - \\
\hline $\mathrm{Mg}$ & 279.553 & 0.0017 \\
\hline $\mathrm{Mn}$ & 257.610 & 0.0195 \\
\hline $\mathrm{Na}$ & 589.592 & 0.0091 \\
\hline $\mathrm{Ni}$ & 232.096 & 0.0012 \\
\hline $\mathrm{P}$ & 178.221 & 0.0005 \\
\hline $\mathrm{P}$ & 213.618 & 0.0012 \\
\hline $\mathrm{S}$ & 181.972 & 0.0027 \\
\hline $\mathrm{Sb}$ & 206.833 & 0.0084 \\
\hline $\mathrm{Si}$ & 252.411 & 0.0856 \\
\hline $\mathrm{Sr}$ & 215.282 & 0.0035 \\
\hline Th & 323.812 & 0.0074 \\
\hline $\mathrm{Ti}$ & 323.904 & 0.0006 \\
\hline $\mathrm{Tl}$ & 276.787 & 0.0004 \\
\hline $\mathrm{U}$ & 311.162 & 0.0282 \\
\hline $\mathrm{Zn}$ & 206.200 & 0.0045 \\
\hline $\mathrm{Zr}$ & 343.823 & 0.0014 \\
\hline
\end{tabular}

- Lithium and boron are the main constituents of the glass blank.

\subsubsection{Radioactive Glass Sample and Analysis Sequence}

WTP plans to collect four samples of feed before and eight samples after addition of glass former chemicals. Therefore, this study required analysis of two process batches of radioactive samples: one batch of four samples and another batch of eight samples. Since the task plan allowed use of previously made glass coupons, the AY-102 radioactive glass coupon prepared at SRNL was utilized in this study. The hot AY-102 glass contained Sc internal standard. The details of the glass coupon preparation and sample dose rates can be found in WSRC-TR-2006-00003.

Both analytical batches included blank and quality control samples (24590-WTP-RPT-OP-06-001, $L A-I C P$-AES Analysis Method for Hanford Vitrification Process). Analytical reference glass (ARG-1) was used as the laboratory control sample (LCS), and the lithium borate glass was utilized as a blank. The sequence of analysis for a batch of four samples requires seven analyses (ARG-1, AY-102, AY-102, Blank, AY-102, AY-102, ARG-1), and a batch of eight samples requires 11 analyses (ARG-1, AY-102, AY-102, AY-102, AY-102, Blank, AY-102, AY-102, AY-102, AY-102, ARG-1). Each AY-102 analysis was treated as a separate sample and was subjected to the 
unloading and loading process in between each analysis to keep a running account of the analytical time.

\subsubsection{Precision and Accuracy}

The data from the analysis of AY-102 were evaluated for precision. The precision (Table 8) for most of the elements was about $5 \%$ relative standard deviation (RSD). The data presented in Table 8 are the average of 12 analyses in each batch. This indicates that the LA-ICP-AES analysis method produced consistent results and that the glass coupon preparation was well controlled and generated homogeneous product. The higher RSDs for some elements can be attributed to their poor sensitivity. Generally when concentration is small and sensitivity is low, higher deviations are seen. The consistency in precision indicates the stable performance of the laser unit.

The accuracy was evaluated for the scoping study with ARG-1 and AY-102. The ARG-1 was used as an LCS, and AY-102 was treated as an unknown sample. The analyses were conducted in the sequence as described in Section 3.2.9. The concentration calculations were made by the vendor-supplied instrument software. ${ }^{3}$ The data generated by the ICP-AES were corrected using an internal standard correction.

The ICP-AES software generated data in terms of weight percent concentration at specified wavelengths. The internal standard correction was applied to account for differences in matrices of calibration standards and samples. Since Sc was present in both calibration standards and samples, a simplistic approach of direct ratio of internal standard concentration to analyte concentration was applied to achieve final results.

The ARG-1 results are summarized in Table 12. The accuracy of analysis was compared within $\pm 15 \%$ for a number of elements ( $\mathrm{Al}, \mathrm{B}, \mathrm{Fe}, \mathrm{Li}, \mathrm{Na}, \mathrm{Ti}$ ), between $15 \%$ and $25 \%$ for $\mathrm{K}$ and $\mathrm{Mn}$, and higher for $\mathrm{P}, \mathrm{Cr}, \mathrm{Ca}, \mathrm{Mg}, \mathrm{Si}, \mathrm{Ni}$. The elements in lower concentrations were not detected.

The LA-ICP-AES AY-102 coupon analysis results were evaluated relative to the wet chemistry ICP-AES results (Table 13). During the wet chemistry testing at SRNL (WSRC-TR-2005-00396, Evaluation of Wet Chemical ICP-AES Elemental Analysis Methods Using both Actual and Simulated Hanford Waste Treatment Plant Samples - Phase II Report, and WSRC-TR-2005-00169, Evaluation of Wet Chemical ICP-AES Elemental Analysis Methods Using Simulated Hanford Waste Samples - Phase I Interim Report) the results were generated by two different methods: cesium carbonate fusion and sodium peroxide fusion methods. The LA-ICP-AES results compared within $\pm 15 \%$ for $\mathrm{Al}, \mathrm{B}, \mathrm{Ca}, \mathrm{Fe}, \mathrm{Li}, \mathrm{Mg}, \mathrm{Na}, \mathrm{Ni}, \mathrm{Si}$, and Ti. While the values for $\mathrm{P}$ and $\mathrm{Cr}$ were about $25 \%$ less than the SRNL reported values, the values for $\mathrm{Mn}$ and $\mathrm{Zn}$ were higher. The abundance of $\mathrm{Cd}, \mathrm{K}, \mathrm{Sb}, \mathrm{Sr}$, and $\mathrm{Zr}$ were below measurable level of the instrument and were not detected. The accuracy for $\mathrm{S}$ was not assessed because of the uncertainty in the reported value. The instrument calibration curve for $\mathrm{Cr}$ was not valid. The calculations were reprocessed manually to generate the numbers reported here. Additional work is required to confirm and validate the line selection for $\mathrm{Cr}$.

${ }^{3}$ Activa Analyst ver. 5.4 is a registered trademark of HORIBA Jobin Yvon Inc., Edison, New Jersey. 
RPP-RPT-39823, Rev. 0

Table 12. Reported and Analyzed Concentrations (wt\%) in ARG-1 Glass Coupon

\begin{tabular}{|lc|c|c|c|}
\hline \multicolumn{2}{|c|}{$\begin{array}{c}\text { Element and } \\
\text { Wavelength (nm) }\end{array}$} & $\begin{array}{c}\text { Analyzed } \\
\text { Concentration }\end{array}$ & $\begin{array}{c}\text { PNNL } \\
\text { Reported } \\
\text { Concentration }\end{array}$ & $\begin{array}{c}\text { \% } \\
\text { Difference }\end{array}$ \\
\hline $\mathrm{Al}$ & 226.346 & 2.697 & 2.47 & 9.19 \\
\hline $\mathrm{B}$ & 181.724 & 2.748 & 2.65 & 3.70 \\
\hline $\mathrm{B}$ & 249.773 & 3.007 & 2.65 & 13.47 \\
\hline $\mathrm{Ca}$ & 183.958 & 1.900 & 1.01 & 88.12 \\
\hline $\mathrm{Ca}$ & 317.933 & 1.601 & 1.01 & 58.51 \\
\hline $\mathrm{Cd}$ & 226.502 & - & - & - \\
\hline $\mathrm{Cr}$ & 205.571 & 0.048 & 0.068 & 28.75 \\
\hline $\mathrm{Fe}$ & 259.940 & 8.691 & 9.81 & 11.41 \\
\hline $\mathrm{K}$ & 766.490 & 1.736 & 2.22 & 21.80 \\
\hline $\mathrm{Li}$ & 670.792 & 1.572 & 1.48 & 6.22 \\
\hline $\mathrm{Mg}$ & 279.553 & 0.927 & 0.525 & 76.57 \\
\hline $\mathrm{Mn}$ & 257.610 & 1.763 & 1.47 & 19.93 \\
\hline $\mathrm{Na}$ & 589.592 & 7.873 & 8.31 & 5.26 \\
\hline $\mathrm{Ni}$ & 232.096 & 1.688 & 0.817 & 106.61 \\
\hline $\mathrm{P}$ & 178.221 & 0.267 & 0.118 & 126.27 \\
\hline $\mathrm{P}$ & 213.618 & 0.085 & 0.118 & 27.97 \\
\hline $\mathrm{S}$ & 181.972 & 0.060 & - & - \\
\hline $\mathrm{Sb}$ & 206.833 & - & - & - \\
\hline $\mathrm{Si}$ & 252.411 & 28.475 & 22.3 & 27.69 \\
\hline $\mathrm{Sr}$ & 215.282 & - & 0.0034 & - \\
\hline $\mathrm{Th}$ & 323.812 & - & - & - \\
\hline $\mathrm{Ti}$ & 323.904 & 0.794 & 0.701 & 13.27 \\
\hline $\mathrm{Tl}$ & 276.787 & - & - & - \\
\hline $\mathrm{U}$ & 311.162 & - & - & - \\
\hline $\mathrm{Zn}$ & 206.200 & - & 0.016 & \\
\hline $\mathrm{Zr}$ & 343.823 & - & 0.104 & - \\
\hline & & & & \\
\hline
\end{tabular}

- Not detected 
Table 13. Analyzed and Reported Elemental Concentrations (wt\%) in AY-102 Glass Coupon

\begin{tabular}{|c|c|c|c|c|c|c|}
\hline \multirow{2}{*}{\multicolumn{2}{|c|}{$\begin{array}{c}\text { Elem ent and } \\
\text { Wavelength } \\
(\mathrm{nm})\end{array}$}} & \multirow[b]{2}{*}{$\begin{array}{c}\text { Analyzed } \\
\text { Concentration }\end{array}$} & \multicolumn{4}{|c|}{ Reported Concentration } \\
\hline & & & $\begin{array}{l}\mathrm{Na}_{2} \mathrm{O}_{2} \\
\text { Fusion }\end{array}$ & $\begin{array}{c}\% \\
\text { Difference }\end{array}$ & $\begin{array}{c}\text { Cs } \\
\text { Carbonate } \\
\text { Digestion } \\
\end{array}$ & $\begin{array}{c}\% \\
\text { Difference }\end{array}$ \\
\hline $\mathrm{Al}$ & 226.346 & 3.671 & 3.230 & 13.6 & 3.090 & 18.8 \\
\hline $\mathrm{B}$ & 249.773 & 3.446 & 3.170 & 8.7 & 2.980 & 15.6 \\
\hline $\mathrm{Ca}$ & 183.958 & 0.743 & 0.672 & 10.5 & 0.414 & 79.4 \\
\hline $\mathrm{Cd}$ & 226.502 & - & 0.024 & - & 0.044 & - \\
\hline $\mathrm{Cr}$ & 205.571 & 0.154 & 0.244 & 31.25 & 0.208 & 25.96 \\
\hline $\mathrm{Fe}$ & 259.940 & 8.547 & 9.600 & 11.0 & 9.650 & 11.4 \\
\hline $\bar{K}$ & 766.490 & - & 6.530 & - & 5.390 & - \\
\hline$\overline{\mathrm{Li}}$ & 670.792 & 1.399 & 1.620 & 13.6 & 1.510 & 7.3 \\
\hline $\mathrm{Mg}$ & 279.553 & 0.090 & 0.106 & 15.4 & 0.095 & 5.6 \\
\hline $\mathrm{Mn}$ & 257.610 & 2.789 & 2.050 & 36.0 & 2.070 & 34.7 \\
\hline $\mathrm{Na}$ & 589.592 & 9.516 & - & - & 8.640 & 10.1 \\
\hline $\mathrm{Ni}$ & 232.096 & 0.521 & 0.573 & 9.1 & 0.468 & 11.3 \\
\hline $\mathrm{P}$ & 178.221 & 0.796 & 1.010 & 21.2 & 1.070 & 25.7 \\
\hline $\mathrm{S}$ & 181.972 & 0.054 & $<0.142$ & & $<0.193$ & - \\
\hline $\mathrm{Sb}$ & 206.833 & - & 0.446 & & 0.435 & - \\
\hline $\mathrm{Si}$ & 252.411 & 27.060 & 23.800 & 13.7 & 24.200 & 11.8 \\
\hline $\mathrm{Sr}$ & 215.282 & - & 0.517 & & 0.371 & \\
\hline Th & 323.812 & - & 0.250 & & 0.341 & - \\
\hline $\mathrm{Ti}$ & 323.904 & 0.073 & 0.074 & 0.54 & 0.063 & 16.3 \\
\hline $\mathrm{Tl}$ & 276.787 & - & 2.530 & & 2.510 & - \\
\hline $\mathrm{U}$ & 311.162 & - & 1.960 & & 1.590 & - \\
\hline $\mathrm{Zn}$ & 206.200 & 0.997 & 0.690 & 44.4 & 0.684 & 45.7 \\
\hline $\mathrm{Zr}$ & 343.823 & - & - & & 0.391 & - \\
\hline
\end{tabular}

- Not detected

Because of the lack of calibration curves, the concentration for Th, U, and Tl were not calculated by the instrument directly as for other elements. However, it was possible to calculate these concentrations by using other approaches such as surrogate calibration. The data presented in Table 14 were calculated using $\mathrm{Ti}$ as a surrogate element. The $\mathrm{Th} / \mathrm{Ti}, \mathrm{Tl} / \mathrm{Ti}$, and $\mathrm{U} / \mathrm{Ti}$ ratios were derived from National Institute of Standards and Technology SRM 610 glass, and the ratios were applied to the Ti calibration curve for concentration calculations. The instrument response values were used directly in these calculations. Because of uncertainty in reported value of $\mathrm{Tl}$ in SRM 610, the data for this element turned out to be very low as compared to the reported value. For comparison purposes, $\mathrm{Zn}$ data were also calculated using the surrogate calibration, and the results are comparable to the SRNL reported values (Table 13). 
Table 14. Analyzed and Reported Concentrations (wt \%) of Th, Tl, and U in AY-102 Glass

\begin{tabular}{|c|c|c|c|}
\hline \multirow[b]{2}{*}{$\begin{array}{c}\text { Element and } \\
\text { Wavelength }(\mathrm{nm})\end{array}$} & \multirow[b]{2}{*}{$\begin{array}{c}\text { Analyzed Value } \\
\text { Laser Ablation }\end{array}$} & \multicolumn{2}{|c|}{ Reported Concentration } \\
\hline & & $\begin{array}{l}\mathrm{Na}_{2} \mathrm{O}_{2} \\
\text { Fusion }\end{array}$ & $\begin{array}{c}\text { Cs Carbonate } \\
\text { Digestion }\end{array}$ \\
\hline Th $\quad 323.812$ & 0.53 & 0.25 & 0.34 \\
\hline 276.787 & 0.04 & 2.53 & 2.51 \\
\hline 311.162 & 1.08 & 1.96 & 1.95 \\
\hline 206.200 & 0.61 & 0.69 & 0.68 \\
\hline
\end{tabular}

\subsubsection{Operator and Day Variability}

The scoping study required that the analyses be performed by different chemists on three different days. The objective of this study was to demonstrate the robustness of the technique to support the vitrification process. When the WTP plant will be running $24 / 7$, the different analysts will perform analyses on different shifts. To be consistent with the task plan, the first batch of four AY-102 samples was analyzed by analyst 1 . In the second batch of eight AY-102 samples, the first four samples were analyzed by analyst 1 , and the remaining four samples were analyzed by analyst 2 . The whole set was repeated to check the reproducibility of the analysis. The data presented in Table 15 indicate that the data obtained by two analysts on three different days was comparable. The method performance meets the day-to-day variability and requirements defined in Appendix A.

\subsubsection{Turnaround Time Study}

The TAT study evaluated total time required from sample receipt to data generation and included the following steps: (a) sample preparation, (b) analysis, and (c) data reduction. The primary objective of the LA-ICP-AES testing was to determine the sample TAT for performing sample preparation and analysis inside the hot cell. Times were not recorded for the following operational activities that did not directly influence the ability to meet the target TAT because in an operational mode these activities are assumed to be performed prior to receipt of samples:

a. Weighing of fusion flux in vials and transferring vials to the hot cell.

b. Preparing the calibration standard, blank, and LCS glass coupons and transferring them to the hot cell.

c. Staging laboratory supplies at the work station that are needed for procedure execution.

d. Initializing and warm-up of laser ablation unit and ICP-AES.

e. Calibrating the LA-ICP-AES.

The LA-ICP-AES time study results were obtained from analytical work that mimics the WTP production laboratory's analysis of the HLW samples. The summary of the time required for each category and substeps is given in Table 16. 
Table 15. Elemental Concentration (wt\%) of AY-102 Analyzed by Different Operators on Different Days

\begin{tabular}{|c|c|c|c|c|c|c|c|c|c|}
\hline \multicolumn{2}{|c|}{$\begin{array}{c}\text { Element and } \\
\text { Wavelength }(\mathrm{nm})\end{array}$} & \multirow{2}{*}{$\begin{array}{c}\begin{array}{c}\text { Day } 1 \\
\text { Operator } 1\end{array} \\
3.893\end{array}$} & \multirow{2}{*}{$\begin{array}{c}\begin{array}{c}\text { Day } 2 \\
\text { Operator } \mathbf{1}\end{array} \\
3.288\end{array}$} & \multirow{2}{*}{$\begin{array}{c}\begin{array}{c}\text { Day 2 } \\
\text { Operator 2 }\end{array} \\
4.017\end{array}$} & \multirow{2}{*}{$\begin{array}{c}\begin{array}{c}\text { Day } 3 \\
\text { Operator } \mathbf{1}\end{array} \\
3.303\end{array}$} & \multirow{2}{*}{$\begin{array}{c}\begin{array}{c}\text { Day } 3 \\
\text { Operator } \mathbf{1}\end{array} \\
3.258\end{array}$} & \multirow{2}{*}{$\begin{array}{c}\text { Day 3 } \\
\text { Operator } 2 \\
4.265\end{array}$} & \multirow{2}{*}{$\frac{\text { Average } \pm \mathbf{\sigma}}{3.671 \pm 0.442}$} & \multirow{2}{*}{$\begin{array}{c}\begin{array}{c}\text { Percent } \\
\text { Variation }\end{array} \\
12.0\end{array}$} \\
\hline $\mathrm{Al}$ & 226.346 & & & & & & & & \\
\hline $\mathrm{B}$ & 181.724 & 4.061 & 3.367 & 4.064 & 3.218 & 5.457 & 4.020 & $4.031 \pm 0.792$ & 19.7 \\
\hline $\mathrm{B}$ & 249.773 & 4.138 & 3.051 & 3.766 & 3.038 & 2.972 & 3.709 & $3.446 \pm 0.489$ & 14.2 \\
\hline $\mathrm{Ca}$ & 183.958 & 0.810 & 0.541 & 0.773 & 0.583 & 1.048 & 0.700 & $0.743 \pm 0.182$ & 24.6 \\
\hline $\mathrm{Ca}$ & 317.933 & 0.419 & 0.380 & 0.432 & 0.308 & 0.306 & 0.417 & $0.377 \pm 0.057$ & 15.1 \\
\hline $\mathrm{Cd}$ & 226.502 & - & - & - & - & - & - & - & - \\
\hline $\mathrm{Cr}$ & 205.571 & 0.522 & 0.292 & 0.491 & 0.393 & 0.557 & 0.714 & $0.495 \pm 0.144$ & 29.2 \\
\hline $\mathrm{Fe}$ & 259.940 & 9.774 & 7.613 & 8.435 & 7.220 & 8.704 & 9.537 & $8.547 \pm 1.015$ & 11.9 \\
\hline $\mathrm{K}$ & 766.490 & - & - & - & - & - & - & - & \\
\hline $\mathrm{Li}$ & 670.792 & 1.432 & 1.456 & 1.526 & 1.132 & 1.500 & 1.348 & $1.399 \pm 0.144$ & 10.3 \\
\hline $\mathrm{Mg}$ & 279.553 & 0.109 & 0.086 & 0.117 & 0.056 & 0.054 & 0.116 & $0.090 \pm 0.029$ & 32.5 \\
\hline $\mathrm{Mn}$ & 257.610 & 3.181 & 2.342 & 2.975 & 2.291 & 2.707 & 3.237 & $2.789 \pm 0.411$ & 14.7 \\
\hline $\mathrm{Na}$ & 589.592 & 8.950 & 9.452 & 9.019 & 8.733 & 10.885 & 10.057 & $9.516 \pm 0.818$ & 8.6 \\
\hline $\mathrm{Ni}$ & 232.096 & 0.564 & 0.301 & 0.722 & 0.505 & 0.355 & 0.680 & $0.521 \pm 0.169$ & 32.5 \\
\hline $\mathrm{P}$ & 178.221 & 0.689 & 0.639 & 0.899 & 0.608 & 1.117 & 0.821 & $0.796+0.193$ & 24.2 \\
\hline $\mathrm{P}$ & 213.618 & 0.506 & 0.331 & 0.570 & 0.366 & 0.337 & 0.497 & $0.435 \pm 0.102$ & 23.5 \\
\hline $\mathrm{S}$ & 181.972 & 0.077 & 0.059 & 0.065 & 0.031 & 0.054 & 0.036 & $0.054 \pm 0.017$ & 32.4 \\
\hline $\mathrm{Sb}$ & 206.833 & - & - & - & - & - & - & - & - \\
\hline $\mathrm{Si}$ & 252.411 & 31.574 & 23.897 & 28.766 & 24.107 & 26.222 & 27.797 & $27.060 \pm 2.941$ & 10.9 \\
\hline $\mathrm{Sr}$ & 215.282 & - & - & - & - & - & - & - & - \\
\hline $\mathrm{Th}$ & 323.812 & - & - & - & - & - & - & - & - \\
\hline $\mathrm{Ti}$ & 323.904 & 0.082 & 0.078 & 0.067 & 0.066 & 0.075 & 0.073 & $0.073 \pm 0.006$ & 8.1 \\
\hline $\mathrm{Tl}$ & 276.787 & - & - & - & - & - & - & - & - \\
\hline $\mathrm{U}$ & 311.162 & - & - & - & - & - & - & - & - \\
\hline $\mathrm{Zn}$ & 206.200 & 1.011 & 0.770 & 1.055 & 0.929 & 1.027 & 1.187 & $0.997 \pm 0.139$ & 14.0 \\
\hline $\mathrm{Zr}$ & 343.823 & - & - & - & - & - & - & - & - \\
\hline
\end{tabular}

- Not detected (below detection limit) 
RPP-RPT-39823, Rev. 0

Table 16. Turnaround Time Study

\begin{tabular}{|c|c|c|}
\hline General Steps & Activity & Time \\
\hline \multirow[t]{3}{*}{ Sample preparation } & Details in Table 1 & 1 hour 45 minutes \\
\hline & $\begin{array}{l}\text { Estimated fusion time for batch } 1 \\
\text { (four samples) }\end{array}$ & 2 hours 45 minutes \\
\hline & $\begin{array}{l}\text { Estimated fusion time for batch } 2 \\
\text { (eight samples) }\end{array}$ & 3 hours 45 minutes \\
\hline \multirow[t]{7}{*}{ Sample analysis } & Load sample & 2 minutes \\
\hline & Purge laser cell & 1.5 minutes \\
\hline & Stabilize ICP-AES & 1.5 minutes \\
\hline & Analysis & 10 minutes \\
\hline & Total analysis time/sample & 15 minutes \\
\hline & Time for analysis of batch 1 & 1 hour 45 minutes \\
\hline & Time for analysis of batch 2 & 2 hours 45 minutes \\
\hline \multirow[t]{3}{*}{ Data reduction/verification } & Internal standard Correction & 2 hours \\
\hline & Grand total for batch 1 & 6 hours 30 minutes \\
\hline & Grand total for batch 2 & 8 hours 30 minutes \\
\hline
\end{tabular}

The time for fabricating one glass coupon was 1 hour 45 minutes (Table 1). The first batch will require preparation of four glass coupons. If the WTP acquires a furnace large enough to accommodate eight samples, the sample drying, fusion, and cooling for four samples of batch 1 can be done in parallel. Similarly, the eight samples of batch 2 can be dried, fused, and cooled at the same time. The additional time required to process each sample will be only for remaining steps (i.e., weighing the sample aliquot, mixing fusion flux, etc.) of the sample preparation procedure. Table 1 indicates that these remaining steps can be completed in 15 minutes. This will add an extra hour to the batch 1 samples and 2 hours to the batch 2 samples. Therefore, the time to complete the sample preparation for batch 1 and batch 2 can be estimated to be 2 hours 45 minutes and 3 hours 45 minutes, respectively.

The analysis time for each sample, as indicated in Table 16, is 15 minutes. According to Section 3.2.8, batch 1 is comprised of a total of seven analyses and batch 2 of 11 analyses. Therefore, the analysis of batch 1 was completed in 1 hour 45 minutes and batch 2 in 2 hours 45 minutes. The data reduction and verification for each batch can be accomplished in 2 hours time. The data reduction time for the $\mathrm{Th}, \mathrm{Tl}$, and $\mathrm{U}$ calculations was excluded as these activities will be automated when the instrument is installed at WTP. The overall TAT for a process batch of four samples is estimated at 6 hours 30 minutes and for a batch of eight samples is 8 hours 30 minutes. Both TATs are less than 9 hours and meet the WTP requirement. 


\subsubsection{Analysis of 241-AN-102}

The applicability of the method was reassessed again by analyzing a radioactive waste glass sample prepared from 241-AN-102 tank material. The 241-AN-102 material was converted to a glass coupon as described in Section 3.1 and then split into two sections for analysis. One part was analyzed by Advanced Technologies and Laboratories International, Inc. (ATL) using a conventional dissolution followed by the standard laboratory ICP-AES method; and the other part was analyzed using the LA-ICP-AES method in Appendix F (ATS-LT-505-105, "222-S Laboratory Laser Ablation-Inductively Coupled Plasma Atomic Emission Spectrometry Analysis"). A glass sample prepared from 241-AN-102 and an ARG-1 glass standard provided by SRNL were analyzed using both approaches. The glass samples analyzed using the standard laboratory methods were ground into small particles of glass prior to analysis. ATL prepared and analyzed the 241-AN-102 and ARG-1 glass samples in accordance with procedure LA-505-114, "Microwave Assisted Acid Digestion of Air Filter Media, Wipes, and Bulk Materials for Analysis by Inductively Coupled Plasma." Subsequent analyses were performed by ICP-AES using procedure LA-505-161, "Inductively Coupled Plasma (ICP) Emission Spectrometric Method for the Thermo Jarrell Ash Type 61E."

The LA-ICP-AES data were obtained using procedure ATS-LT-505-105 (see Table 17). The analytical results obtained by LA-ICP-AES showed some of the elements of interest were below the method detection limit; however, the results for the other elements were consistently higher than ATL data. The discrepancy may indicate that the test recipe for producing glass from Hanford tank waste needs to be modified to increase sample mass in the glass matrix. This would increase the LA-ICP-AES method accuracy. Additionally improving the method used for introducing the internal standard into the glass matrix will also improve the method accuracy.

\section{QUALITY ASSURANCE AND SAFETY}

This task was conducted following the guidelines established by APD within the administrative structure of the 222-S Laboratory. The work was performed using the Integrated Safety Management System approach. The work was completed under the WRPS contract with the U.S. Department of Energy, Office of River Protection. The WRPS contract specifies that WRPS operate a quality assurance program based on the requirements of Title 10, Code of Federal Regulations, Part 830, "Nuclear Safety Management," Subpart A (10 CFR 830, Subpart A); DOE O 414.1C, Quality Assurance, for facilities and projects within the scope of work; and NQA-1-2004, "Quality Requirements for Nuclear Facility Applications." (Contract No. DE-RP27-07RV14800, Section C.3.2.4 Quality)

All employees are responsible for performing work in accordance with the documented requirements. Those employees performing oversight and verification have the authority and responsibility to identify quality problems, recommend solutions, and verify implementation of effective corrective actions. Employees have the authority to stop work when they determine a situation represents an imminent hazard that places their personal safety, the safety of their coworkers, or the environment at risk. 
Table 17. LA-ICP-AES and ICP-AES Method Comparison (wt \%)

\begin{tabular}{|c|c|c|c|c|}
\hline \multirow[b]{2}{*}{ Elements } & $\begin{array}{c}\text { LA-ICP-AES } \\
(w t \%)\end{array}$ & $\begin{array}{c}\text { ICP-AES } \\
(w t \%)\end{array}$ & $\begin{array}{c}\text { LA-ICP-AES } \\
(w t \%)\end{array}$ & $\begin{array}{c}\text { ICP-AES } \\
(\mathbf{w t} \%)\end{array}$ \\
\hline & \multicolumn{2}{|c|}{ Tank 241-AN-102 } & \multicolumn{2}{|c|}{ ARG-1 } \\
\hline $\mathrm{Al}$ & 0.58 & 0.175 & 4.58 & 1.65 \\
\hline$B$ & 37.31 & 20.90 & 2.45 & 2.51 \\
\hline $\mathrm{B}$ & 46.03 & 20.90 & 2.99 & 2.51 \\
\hline $\mathrm{Ca}^{*}$ & $<$ & $<$ & 2.18 & 0.898 \\
\hline $\mathrm{Ca}^{*}$ & $<$ & $<$ & 2.30 & - \\
\hline $\mathrm{Cd}$ & $<$ & $<$ & $<$ & $<$ \\
\hline $\mathrm{Cr}$ & $<$ & 0.217 & 0.09 & 0.0635 \\
\hline $\mathrm{Fe}$ & 1.00 & 0.0056 & 11.66 & 9.11 \\
\hline $\mathrm{K}$ & $<$ & 0.171 & 3.06 & 2.42 \\
\hline $\mathbf{L i}$ & 27.51 & 7.97 & 2.42 & 1.70 \\
\hline $\mathrm{Mg}$ & $<$ & $<$ & 1.28 & 0.437 \\
\hline $\mathrm{Mn}$ & $<$ & $<$ & 2.77 & 1.32 \\
\hline $\mathrm{Na}$ & 11.72 & 2.58 & 10.22 & 8.84 \\
\hline $\mathrm{Ni}$ & $<$ & $<$ & 2.25 & 0.750 \\
\hline $\mathrm{P}^{\ddagger}$ & 0.02 & $<$ & 0.18 & $<$ \\
\hline $\mathrm{P}^{\ddagger}$ & $<$ & $<$ & 0.07 & - \\
\hline $\mathrm{S}$ & 0.27 & 0.0795 & 0.03 & $<$ \\
\hline $\mathrm{Sb}$ & $<$ & $<$ & $<$ & $<$ \\
\hline $\mathrm{Si}$ & $<$ & 3.57 & 31.20 & 21.3 \\
\hline $\mathrm{Sr}$ & $<$ & $<$ & $<$ & 0.00297 \\
\hline Th & $<$ & $<$ & $<$ & $<$ \\
\hline $\mathrm{Ti}$ & 0.06 & $<$ & 1.03 & 0.5960 \\
\hline $\mathrm{T} 1$ & $<$ & $<$ & $<$ & $<$ \\
\hline $\mathrm{U}$ & $<$ & $<$ & $<$ & $<$ \\
\hline $\mathrm{Zn}$ & $<$ & $<$ & $<$ & 0.0163 \\
\hline $\mathrm{Zr}$ & $<$ & $<$ & $<$ & 0.0866 \\
\hline
\end{tabular}

* More than one emission line measurement obtained for LA-ICP-AES data.

$<$ The concentration in the sample was less than the method detection limit.

The installation of the LA-ICP-AES system required significant preparation including reduction of radiological inventory to as low as reasonably achievable (ALARA), job planning with worker involvement, and joint review committee approvals. System mockups and dry runs were performed as part of workforce training.

Analytical tests were performed in accordance with HNF-SD-CP-QAPP-016, 222-S Laboratory Quality Assurance Plan, and DOE/RL-96-68, Hanford Analytical Services Quality Assurance Requirements Documents (HASQARD). No analytical data were generated to support WTP process use or any waste characterization. The information present here is limited to the assessment of the applicability of this technology to address future technology needs. The information in this report does not support LA-ICP-AES method validation. Method validation was not within the authorized scope of work for this project. 
The LA-ICP-AES instrumentation provided by WTP was successfully received and adapted to the $11 \mathrm{~A}$ hot cells. The APD group at the 222-S Laboratory has demonstrated acceptable TAT of less than 9 hours and the LA-ICP-AES system has shown to provide sufficient data sensitivity and accuracy to meet the needs of WTP.

\section{DISCUSSION AND RECOMMENDATIONS}

The LA-ICP-AES instrumentation provided by WTP was successfully received and adapted to the 11A hot cells. The APD group at the 222-S Laboratory has demonstrated acceptable TAT of less than 9 hours. The procedure was shown to provide sufficient data sensitivity, accuracy, and precision of the LA-ICP-AES method. This includes development of an in-cell glass fusion procedure for the preparation of melter feed into a glass matrix that can be analyzed. The LA-ICP-AES method does offer WTP the ability to receive and analyze feed material in one shift as a process control analysis for the feed to the glass melter.

This study disclosed some areas where the equipment and analytical methodology should receive additional optimization:

a. Design Improvements:

1. As noted in the report, the torch positioning mechanism became jammed. The problem remained hidden for some time as the adjustment for the horizontal position is set and moved at only one point. Using this design can result in an operator believing the torch is moving in a straight horizontal line, but if the mechanism is jammed, the torch is actually being moved in an arc due to increasing tension on one side of the adjustment mechanism. This design issue can be prevented by redesigning the adjustment mechanism to engage the torch support at two opposing positions.

2. The glove box was designed with a load-in/load-out port that is designed to always push material into the glove box. Material can be loaded out only by cutting it up into small pieces and bagging out, but to replace the bag with a new one required the retaining ring and unused bag to be pushed into the glove box. This makes the loadin/load-out process very inefficient and always leaves waste residue in the working space inside the glove box. The original design of a "French Can" port or a doubledoor pass-through would resolve this issue.

3. The system was operated at the 222-S Laboratory in two different configurations: first as a glove box as designed and secondly installed in a laboratory hood. The hood configuration was set by removing two gloves from the glove ports and adjusting the flow rates for air entering the enclosure. There were no issues with dose rates or contamination in either configuration, and the change had no impact on the performance of the LA-ICP-AES. Operating the system in the fume hood configuration greatly simplifies standard operations such as maintenance or waste management. The fume hood installation should be evaluated for use at the WTP laboratory. 
b. Calibration and instrument sensitivity:

1. The wavelength selection to this point is limited to the vendor-selected wavelengths used in the original vendor tests. Method performance can be improved by optimization of the wavelength selection to the matrix being analyzed. Additional testing and optimization of alternate wavelengths should be performed.

2. A proven method for producing glass standards in the waste matrices that will be processed at WTP need to be validated. The prepared standards should include a wider range of elements and compositions for bracketing the analysis of Hanford tank waste vitrification process samples.

3. It may be possible to calibrate the LA-ICP-AES using liquid standards and understanding the physics of the aerosol transport. The method currently uses internal tracers to monitor the aerosol so this change may be implemented simply by adjusting the torch arrangement to introduce water to the plasma while the laser is in operation. The impact of such a change should be investigated.

4. It was noticed that processing data offline can in some cases generate better data fits. Validation of offline data calculations becomes necessary for process support. More work is required to standardize and automate data processing and the methodology used for internal standard corrections.

5. It has been suggested that a pressed pellet sample preparation similar to what is currently used in X-ray sample analysis may be able to replace the glass fusion sample preparation used in this study. If such a sample could be successfully ablated, there would be time saved in the sample preparation steps. Additional investigation would be required to study and evaluate this option.

Overall the results obtained from the LA-ICP-AES analysis of the radioactive AY-102 glass are satisfactory. The adaptation of the developed method (for hot cell testing using radioactive samples) successfully demonstrated the acceptance of selected technology for meeting the rapid TAT requirements for monitoring the vitrification process.

\section{REFERENCES}

7S110-MFM-07-096, 2007, "Preparation of Glass Coupons from Tank Simulant" (interoffice memorandum from M. F. Marcus to C. M. Seidel, January 25), CH2M HILL Hanford Group, Inc., Richland, Washington.

10 CFR 830, "Nuclear Safety Management," Subpart A-Quality Assurance Requirements, Code of Federal Regulations, as amended.

24590-101-TSA-W000-0004-153-00005 (WTP-RPT-139), 2005, Conventional Non-Dilute West Chemistry Dissolution/ICP-AES Time Study, Battelle-Pacific Northwest Division (PNWD), Richland, Washington (proprietary). 
24590-101-TSA-W000-0004-158-00002 (WTP-RPT-140), 2005, Laser Ablation Study for High Level Waste and Melter Feed Characterization, Battelle-Pacific Northwest Division (PNWD), Richland, Washington (proprietary).

24590-WTP-RPT-OP-06-001, Rev 0, LA-ICP-AES Analysis Method for Hanford Vitrification Process, Bechtel National, Inc., Richland, Washington.

ATS-MP-1027, Management Plan for Waste Treatment Plant Project Work Performed by Analytical Technical Services, CH2M HILL Hanford Group, Inc., Richland, Washington.

ATS-MP-1032, 222-S Laboratory Quality Assurance Plan, Washington River Protection Solutions LLC, Richland, Washington.

DOE O 414.1C, Quality Assurance, U.S. Department of Energy, Washington, D.C.

DOE/RL-96-68, Hanford Analytical Services Quality Assurance Requirements Documents (HASQARD), U.S. Department of Energy, Richland Operations Office, Richland, Washington, as amended.

Ducreux-Zappa, M., and J.-M. Mermet, 1996, "Analysis of glass by UV laser ablation inductively coupled plasma atomic emission spectrometry. Part 1. Effects of the laser parameters on the amount of ablated material and the temporal behaviour of the signal for different types of laser," Spectrochim. Acta Part B, Vol. 51, pp. 321-332.

HNF-SD-CP-QAPP-016, 2005, 222-S Laboratory Quality Assurance Plan, Rev. 9, CH2M HILL Hanford Group, Inc., Richland, Washington.

Kanicky, V., and J.-M. Mermet, 1997, "Selection of Internal Standards for the Determination of Major and Minor Elements in Silicate Rocks and Limestones by Laser Ablation Inductively Coupled Plasma Atomic Emission Spectrometry," Appl. Spectro, Vol. 51, Issue 3, pp. 332-336.

Kanicky, V., V. Otruba, and J.-M Mermet, 1998, "Use of Internal Standardization to Compensate for a Wide Range of Absorbance in the Analysis of Glasses by UV Laser Ablation Inductively Coupled Plasma Atomic Emission Spectrometry," Appl. Spectro., Vol. 52, Number 5, pp. 638-642.

Mermet, J.-M., 1994, "Quality of calibration in inductively coupled plasma atomic emission spectrometry," Spectrochim. Acta Part B, Vol. 49, Issues 12-14, pp. 1313-1324.

NQA-1-2004, Quality Requirements for Nuclear Facility Applications, American Society of Mechanical Engineers, New York, New York

PL-24590 QA00001, 2001, Quality Assurance Project Plan for Testing Programs Generating Environmental Regulatory Data, Rev 0, Bechtel National, Inc., Richland, Washington. 
SRNL-SCS-2005-00019, 2005, Candidates for RPP Glass Standards RPP Glass, Rev 0, Westinghouse Savannah River Company, Aiken, South Carolina.

SRNL-SCS-2005-00052, 2005, Measured Compositions of Candidates for WTP Glass Standards (U), Rev 0, Westinghouse Savannah River Company, Aiken, South Carolina.

Task Order 2005-003, June 2005, "Laser Ablation/Inductively Coupled Plasma-Atomic Emission Spectroscopy (LA-ICP-AES) Study at CHG-222S using Hot-Cell Glovebox Prototype System," CCN: 122474, Bechtel National, Inc., Richland, Washington.

TFC-PLN-02, Rev. B-3, Quality Assurance Program Description, CH2M HILL Hanford Group, Inc., Richland, Washington.

TFC-PLN-30, Rev. A-2, CH2M HILL Analytical Technical Services Quality Assurance Program Plan, CH2M HILL Hanford Group, Inc., Richland, Washington.

WSRC-TR-20005-00169 (SRNL-RPP-2005-00023), SCT-M0SRLE60-00-145-00010, 2005, Evaluation of Wet Chemical ICP-AES Elemental Analysis Methods Using Simulated Hanford Waste Samples - Phase I Interim Report (U), Rev 0A, Westinghouse Savannah River Company, Aiken, South Carolina.

WSRC-TR-2005-00260 (SRNL-RPP-2005-00038), SCT-M0SRLE60-00-216-00002, 2005, The Development of Laser Ablation-Inductively Coupled Plasma-Atomic Emission Spectroscopy for the Analysis of Hanford High Level Waste: Phase 1, Rev 0A, Westinghouse Savannah River Company, Aiken, South Carolina.

WSRC-TR-2005-00396 (SNRL-RPP-2005-00056), SCT-M0SRLE60-00-145-00019, 2005, Evaluation of Wet Chemical ICP-AES Elemental Analysis Methods Using both Actual; and Simulated Hanford Waste Treatment Plant Samples - Phase II Report, Rev 0A, Westinghouse Savannah River Company, Aiken, South Carolina.

WSRC-TR-2006-00003 (SRNL-RPP-2006-00002), SCT-M0SRLE60-00-216-00002, 2006, The Development of Laser Ablation-Inductively Coupled Plasma-Atomic Emission Spectroscopy for the Analysis of Hanford High Level Waste: Phase II, Rev 0A, Westinghouse Savannah River Company, Aiken, South Carolina. 